\title{
DOES INNOVATION STIMULATE EMPLOYMENT? A FIRM-LEVEL ANALYSIS USING COMPARABLE MICRO-DATA FROM FOUR EUROPEAN COUNTRIES
}

\author{
Rupert Harrison \\ Jordi Jaumandreu \\ Jacques Mairesse \\ Bettina Peters \\ Working Paper 14216 \\ http://www.nber.org/papers/w14216
NATIONAL BUREAU OF ECONOMIC RESEARCH
1050 Massachusetts Avenue
Cambridge, MA 02138
August 2008

The authors thank the respective statistical offices for access to the data. We are grateful for comments by Manuel Arellano, Steve Bond, Bronwyn Hall, Daniele Paserman, Alessandro Sembenelli, Luc Soete, Manuel Trajtenberg, John Van Reenen, Marian Vidal-Fernandez, two referees, and the participants at the seminars where preliminary versions of the paper have been discussed. This research has benefited from joint work with the rest of the IEEF team: Laura Abramovsky, Rachel Griffith, Elena Huergo, Norbert Janz, Elizabeth Kremp, Alberto Lopez, Pierre Mohnen, Tobias Schmidt and Helen Simpson. The views expressed herein are those of the author(s) and do not necessarily reflect the views of the National Bureau of Economic Research.

NBER working papers are circulated for discussion and comment purposes. They have not been peerreviewed or been subject to the review by the NBER Board of Directors that accompanies official NBER publications.

(C) 2008 by Rupert Harrison, Jordi Jaumandreu, Jacques Mairesse, and Bettina Peters. All rights reserved. Short sections of text, not to exceed two paragraphs, may be quoted without explicit permission provided that full credit, including $(\mathrm{C}$ notice, is given to the source. 
Does Innovation Stimulate Employment? A Firm-Level Analysis Using Comparable Micro-Data from Four European Countries

Rupert Harrison, Jordi Jaumandreu, Jacques Mairesse, and Bettina Peters

NBER Working Paper No. 14216

August 2008

JEL No. D2,J23,L1,O31,O33

\section{ABSTRACT}

This paper studies the impact of process and product innovations introduced by firms on employment growth in these firms. A simple model that relates employment growth to process innovations and to the growth of sales separately due to innovative and unchanged products is developed and estimated using comparable firm-level data from France, Germany, Spain and the UK. Results show that displacement effects induced by productivity growth in the production of old products are large, while those associated with process innovations, which are likely to be compensated by price decreases, appear to be small. The effects related to product innovations are, however, strong enough to overcompensate these displacement effects.

\author{
Rupert Harrison \\ The Institute for Fiscal Studies \\ 7 Ridgmount Street, London WC1E 7AE. \\ United Kingdom \\ harrison.rupert@googlemail.com \\ Jordi Jaumandreu \\ Department of Economics \\ Universidad Carlos III de Madrid \\ C./ Madrid, 126 \\ 28903 Getafe (Madrid) \\ SPAIN \\ jordij@eco.uc3m.es
}

\author{
Jacques Mairesse \\ INSEE, CREST \\ 15, Boulevard Gabriel PERI \\ 92245 MALAKOFF CEDEX \\ FRANCE \\ and NBER \\ mairesse@ensae.fr \\ Bettina Peters \\ ZEW \\ Postfach 103443 D-68043 Mannheim \\ Germany \\ b.peters@zew.de
}




\section{Introduction}

Innovation is widely considered to be a primary source of economic growth, and policies to encourage firm-level innovation are high on the agenda in most countries. The consequences of innovation for employment are of particular interest, but the relationship between innovation and employment is not particularly well known. On the one hand, the long-run economic impact of innovation on employment is clearly not negative; many decades, and even centuries, of innovation in advanced economies have been accompanied by employment growth instead of the ever-decreasing levels of jobs that many predicted. On the other hand, although the evidence suggests that innovative firms are more likely to survive and grow than firms that do not innovate, our knowledge of the impact of innovation on employment at the firm level remains rather fuzzy. Innovations often destroy jobs, but also estimulate demand for a firm's products and it is unclear to what extent and through what mechanisms the overall employment is affected.

The analysis of the firm-level relationship between innovation and employment is thus an important topic of research. It is expected to shed light on the relationships between firm-level evidence and aggregate outcomes, and this is directly relevant for the design of micro-policies to favour employment growth. The effects of innovation on employment at the firm level are likely to influence the incentives of managers and workers within the firm to resist or encourage innovation, and these incentives will affect the rhythm and even the types of innovations that are introduced and their subsequent effects on prices, output and employment. A better assessment of such effects is thus important for understanding how product and labour market regulations can affect firm-level and economy-wide rates of innovation, and for a well informed implementation of innovation policy.

This paper investigates the effects of innovation on employment at the firm-level, and makes three main contributions to the literature. Firstly, we develop and apply a simple but formal model of innovation and employment that is able to disentangle some of the structural effects at work. In particular, we observe the mix of each firm's output growth between existing and newly introduced products, enabling us to quantify the employment effects of product innovation. Our results enlarge some of the findings of the literature, encompassing and explaining previous evidence. Secondly, the paper uses comparable firmlevel data sets for four large European countries: France, Germany, Spain and the UK. Firms 
in these countries operate in somewhat different economic and institutional environments, and our results identify several robust common effects as well as a few meaningful cross-country differences in the firm-level relationship between innovation and employment. Finally, we present evidence separately for manufacturing and the service sectors. Almost all previous studies have focused exclusively on manufacturing, yet much of the employment creation in the four countries in recent years has been in services.

We take our model to the data by estimating, for each country, a regression relating firms' employment growth to the introduction of process innovations and the two components of sales growth accounted for by "unchanged" and "newly introduced or substantially improved" products, respectively. ${ }^{1}$ We have taken particular care to control for potential sources of correlation between the included variables and the residual by considering different choices of instrumental variables. The results show that product innovations are an important source of firm-level employment growth, while process innovations, which are likely to be associated to price reductions, tend to displace employment moderately. These effects are measured at the firm level, but we discuss how they should be aggregated up to the industry level by taking into account rivalry between competitors and the effects of entry and exit.

The data used in this paper come from the Third Community Innovation Survey (CIS3). These data are gathered on the basis of unified definitions following the "Oslo Manual" (see OECD and Eurostat, 2007), and they are available for a number of European Union countries in a similar format. Basic CIS3 variables (set out in the core questionnaire) include, for each firm in the sample, employment and sales in the years 1998 and 2000, and information about whether the firm has introduced process and product innovations during the period. Particularly useful for our purpose is the variable measuring the share of the firm sales in 2000 stemming from new or significantly improved products introduced since 1998. This variable, which can be viewed as a sales-weighted estimate of the firm product innovations, allows us to decompose total sales in sales of "new" and "old" products. In addition, the survey provides information on firms' $R \& D$ and other innovation expenditures, as well as sources and objectives of innovation, and cooperation and patenting activities. The firmlevel data used for France, Germany, Spain and the UK have been accessed at the national level under confidentiality rules, but the analysis and implementation of the model have been

\footnotetext{
${ }^{1}$ Due to data limitations, the paper considers the growth in total employment without distinguishing between different types of workers (e.g., skilled and unskilled).
} 
discussed and coordinated among the researchers from the four countries. The results of such a cooperative endeavour are stimulating, pointing to consistent regularities across countries and to some differences that are worth investigating further. ${ }^{2}$

The rest of this paper is organised as follows. Section 2 discusses the potential firm-level employment effects of innovation, including a look at the relationships between firm-level and aggregate outcomes, and relates briefly our contribution to the literature. Section 3 develops the model and discusses what effects can be identified using the available data. Section 4 comments on the data and the evidence provided by simple descriptive statistics on employment and innovation outcomes in the four countries. Section 5 presents the main econometric estimates and checks their validity. Section 6 presents a decomposition of firms' employment growth and comments on the differences between the four countries and the manufacturing service sectors. Section 7 concludes. In Appendix A, we present some additional regressions and robustness checks, and in Appendix B, we give details on the construction of the four country samples and on the definition of all the variables used in the empirical analysis.

\section{Employment effects of innovation at the firm level}

\subsection{Process and product innovations}

The potential effects of innovation on firm-level employment are summarised in Table $1 .{ }^{3}$ It is advisable to distinguish between the effects of process innovations, which are directed at improving the production process and hence have a direct impact on productivity and unit costs, and the effects of product innovations, which are mainly undertaken to reinforce demand for a firm's products. In practice, of course, process innovations often accompany product innovations and vice versa. As indicated in Table 1, both types of innovations can be interpreted as the (partly random) result of a firm's investment in R\&D and other innovative activities.

Pure process innovations are likely to reduce the quantities of (most) factors required to obtain a unit of output, including the required labour input. Thus process innovations tend to displace labour for a given output, although the size of such displacement effect will

\footnotetext{
${ }^{2}$ For a companion study also using the CIS3 firm-level data for France, Germany, Spain and the UK, see Griffith, Huergo, Mairesse and Peters (2006).

${ }^{3}$ In this section, we draw on theoretical discussions in several papers, including Nickell and Kong (1989), Van Reenen (1997), Garcia, Jaumandreu and Rodriguez (2002) and the more theoretical works quoted therein.
} 
depend on the extent to which the process improvement is labour or capital-augmenting. The effects of specific identifiable process innovations are additional to those of incremental improvements in efficiency, attributable to factors such learning and spillovers, which also reduce input requirements over time. ${ }^{4}$

Productivity increases from process innovations imply a reduction in unit costs. Depending on the competitive conditions facing the firm, this cost reduction is likely to result in a lower price, which will stimulate demand, and hence output and employment. The size of such compensation effect is largely determined by the elasticity of demand for the firm's products, but is also likely to depend on the behaviour of the agents inside the firm and the nature of market competition. For example, unions may attempt to transform any gains from innovation into higher wages, while managers may take advantage of their firm market power to increase profits. ${ }^{5}$ Both behaviours can dampen or override the compensation effect.

Product innovations may also have productivity effects, even if they are not associated with simultaneous process innovations. The new or improved product may imply a change in the production method and input mix, which could either reduce or increase labour requirements. The extent and direction of these effects must be determined empirically. However, they are likely to be smaller than the positive compensation effects resulting from the increases in demand for a firm's products. The importance of such increases in demand will depend on the nature of competition and the delay with which rivals react to the introduction of new products. In addition, sales of new products may cannibalise some proportion of the firm's existing sales, reducing the size of the compensation effects. Therefore, one should, when possible, distinguish a gross effect and a net effect, the latter taking into account the induced reduction in existing sales.

The service sector has become the largest part of most developed economies, and contrary to traditional wisdom, many areas of the service sector have demonstrated high levels of

\footnotetext{
${ }^{4}$ Production functions frequently account for such ongoing improvements in productivity by including time trends or time dummies when specified and estimated in levels (or, equivalently, constants or time dummies when specified and estimated in first differences). Indicators of specific innovative investments or outcomes, such as knowledge capital stocks or innovation counts, typically account for only a small part of unexplained productivity growth, even when statistically significant. For an illustration of this point, see, for example, the panel data investigations in Hall and Mairesse (1995) and Huergo and Jaumandreu (2004), or the survey by Mairesse and Sassenou (1991).

${ }^{5}$ See Nickell (1999) for a discussion.
} 
innovation and productivity growth. ${ }^{6}$ However, innovation in services is often concerned with changes in organisation, delivery and variety, which are possibly linked to the adoption of Information and Communication Technologies (ICT). ${ }^{7}$ As a result, it is more difficult than in manufacturing to clearly identify new products and to distinguish product innovations from process innovations. Moreover, statistical concepts and measurement in services are currently in a period of change and refinement. As a result of these considerations, while we think it is important to include the service sector in the analysis, one has to bear in mind that the same variables may be more roughly measured than in manufacturing or have interpretations that may be different.

\subsection{Innovation and employment at the aggregate level}

The focus of this paper is on the assessment of the relationship between innovation and employment at the firm level, which raises the crucial question of how the effects estimated at this level of analysis relate to changes at the aggregate level of an industry or a country. There are two main reasons why the aggregate effects of innovation on employment cannot be trivially inferred from average firm-level effects (for example, by adjusting them on the basis of the representativeness of the firms in the study sample relative to the population of firms in the industry or the country).

First, the firm-level compensation effects that we observe do not distinguish between the pure market expansion component and the business-stealing component. 8 At the same time, however, we should recognise that the average firm-level employment outcomes that we observe already embody the effects of business-stealing demand by firms' rivals, even if we do not know their identity or observe them in our sample. This means that, on average, provided that the different types of firms are well represented in our sample, the business-stealing effects will tend to cancel out. However, this does not necessarily happen at more disaggregated levels: we cannot identify, for instance, the degree to which innovation by innovative firms results in business-stealing from non-innovators rather than market expansion.

Secondly, and in a related way, we do not observe entering or exiting firms in our sample of

\footnotetext{
${ }^{6}$ See, for example, Evangelista (2000) for the EU, and Triplett and Bosworth (2004) for the US.

${ }^{7}$ Examples include Internet Banking and the introduction of scanners and computers in Retailing.

${ }^{8}$ Garcia, Jaumandreu and Rodriguez (2002), however, provide a decomposition of these effects by estimating the impact of rivals' actions on the firm's demand. According to their results, market expansion effects dominate the business stealing effects.
} 
continuing firms. Firm entry, which may be the result of innovation, is an important source of employment growth, while exit may be induced by successful innovation and business-stealing by rival firms.

A full industry-level analysis would therefore have to explicitly incorporate entry, exit and competition between rival firms. Evidence on the rivalrous effects of innovation could be obtained by modelling firm demand, while data on entering and exiting firms would be needed to assess the role of entry and exit. Our analysis does not relate directly to aggregate employment effects, but it does provide essential information on the micro-mechanisms that explain aggregate employment growth. However, to draw implications for the aggregate figures, the previous caveats should be taken into consideration.

\subsection{Previous literature on innovation and employment}

A number of previous analyses have provided evidence on the relationship between innovation and employment at the firm level. The survey by Chennels and Van Reenen (2002), although focused on a related but different question, and the one by Spiezia and Vivarelli (2002), provide useful overviews. ${ }^{9}$ Existing studies differ widely in terms of modelling strategies and methods, in particular in the way they address the issues of heterogeneity and endogeneity. Most of them range from the assessment of simple correlations to the estimation of reduced form relations, and only a few have tried a more structural approach. In addition, they exploit different data sets, using sundry measures of innovation, some input-oriented, as R\&D intensity, and others output-oriented, such as innovation and patents counts.

On the whole, product innovation emerges as clearly associated with employment growth, although the balance between displacement and compensation effects appears diverse accross studies (see, for example, Entorf and Pohlmeier, 1991; König, Licht and Buscher, 1995; Van Reenen, 1997; Greenan and Guellec, 2000; Smolny, 1998 and 2002; Garcia, Jaumandreu and Rodriguez, 2002). R\&D investment also tends to be positively related to employment growth (see, for example, Blechinger, Kleinknecht, Licht and Pfeiffer, 1998, and Regev, 1998), although not always (see Brouwer, Kleinknecht and Reijnen, 1993, and Klette and Forre, 1998). By contrast, the effects of process innovation and of the introduction of new technologies are found to range from negative to positive according to the specification (see, for example,

\footnotetext{
${ }^{9}$ The survey by Chennels and Van Reenen focuses mainly on the impact of technological change on the skill and pay structure of labour.
} 
Ross and Zimmerman, 1993, for a negative process innovation effect; Doms, Dunne and Roberts, 1995, or Blanchflower and Burguess, 1999, for positive technology impacts; see also the various effects of process innovations in many of the above papers).

The focus of our paper is the derivation of a simple theoretical model of employment and innovation and the estimation of a few structural effects with the comparable crosscountry data at hand. Our model encompasses most of the relationships estimated in previous analyses and our findings throw light on the reasons why these results could vary across specifications. We compare evidence for the manufacturing and service sectors, whereas almost all of the existing literature has focused exclusively on manufacturing.

Following the first draft of this paper, a few authors have applied some versions of our model to different country data sets: Peters $(2004,2008)$ to Germany; Hall, Lotti and Mairesse (2007) to Italy; and Benavente and Lauterbach (2007) to Chile. They provide results which are much in line with ours.

\section{Theoretical framework and estimation strategy}

\subsection{A two-goods production function}

A firm can produce two types of products: old or only marginally modified products ("old products") and new or significantly improved products ("new products"), which we denote with $i=1$ and $i=2$, respectively. We observe firms in two different years, which we denote $t=1$ and $t=2$, possibly introducing some new products in between. Outputs of old and new products in year $t$ are denoted by $Y_{1 t}$ and $Y_{2 t}$, respectively. In year $t=1$, all products are old products by definition, so $Y_{21}$ is always equal to zero. If the firm does not introduce any new products between the two years, then $Y_{22}$ is also equal to zero. ${ }^{10}$

We assume that the production technology for old and new products presents constant returns to scale in capital, labour and intermediate inputs and can be written as two separable identical production functions with different Hicks-neutral technology parameters $\theta$. That is, omitting the firm subindex for the sake of simplicity, we have:

$$
Y_{i t}=\theta_{i t} F\left(K_{i t}, L_{i t}, M_{i t}\right) e^{\eta+\omega_{i t}} \quad i=1, t=1,2 \text { and } i=2, t=2
$$

\footnotetext{
${ }^{10}$ In practice, in our data, years $t=1$ and $t=2$ are 1998 and 2000, and firms may have already started introducing new products in 1998. This does not affect the rationale of our model, but must be kept in mind in the precise interpretation of our estimates.
} 
where $K, L$ and $M$ stand for capital, labor and intermediate consumption, and $\eta$ is an unobserved firm-idiosyncratic "fixed" effect and $\omega$ stands for product and time-specific productivity shocks with $E\left(\omega_{i t}\right)=0 .{ }^{11}$

We assume that the firm invests in $\mathrm{R} \& \mathrm{D}$ to generate product and process innovations. New products can be produced with higher or lower efficiency than old products, and the firm can influence the efficiency of production of both old and new products by investing in process innovation. The primary interest of our analysis is in estimating the change in efficiency of producing old products $\left(\theta_{12} / \theta_{11}\right)$ as well as the relative efficiency $\left(\theta_{22} / \theta_{11}\right)$ of producing old and new products.

The firm productivity levels are influenced by the unobservable firm-specific effects $\eta$ and idiosyncratic shocks $\omega$. The $\eta^{\prime}$ s represent all the unobservable factors which make a firm more (or less) productive than the average firm using the same technology, i.e., with the same $\theta$. These include any innovation-related characteristics which are likely to raise (lower) productivity permanently (e.g., a superior ability for innovation management, a higher absorptive capacity, a more efficient organization). We call them individual productivity effects. The $\omega^{\prime}$ s are intended to pick up all the unobservable shifts in the production function for reasons other than the development of technology (e.g., unobserved investments, bursts in capacity utilization, labour and temporary organizational problems). We call them (nontechnological) productivity shocks. We do not impose any distributional restriction on these productivity shocks $\omega$, which in particular may be autocorrelated. ${ }^{12}$

\subsection{An employment equation}

We assume that employment and other decisions about inputs are made according to cost minimization given the individual productivity effects $\eta$ and productivity shocks $\omega$ (produc-

\footnotetext{
${ }^{11}$ Our specification allows for the presence of economies of scope. Joint production implies a pair of efficiency terms $\left(\theta_{12}, \theta_{22}\right)$ which can be strictly higher than the pair $\left(\theta_{12}^{\prime}, \theta_{22}^{\prime}\right)$ corresponding to the production of each good separately.

${ }^{12}$ However, we have to consider that the shocks which affect the production of the new products when they are introduced are the shocks already affecting the old products; that is, shocks $\omega_{22}$ and $\omega_{11}$ are the same. This is basically a definitional assumption, which means that the observed reallocations of inputs at the start of a new production do not respond to unobserved shocks but correspond to technology requirements. This assumption avoids the inclusion of an additional error term involving the ratio of the outputs of new and old products in the derivation of our growth employment equation (1) below.
} 
tivity shocks are observed by the firm before deciding the input quantities). Given technology, the relevant cost functions have the form:

$$
C\left(w_{i t}, Y_{i t}, \theta_{i t}\right)=c\left(w_{i t}\right) \frac{Y_{i t}}{\theta_{i t} e^{\eta+\omega_{i t}}}+F_{i}
$$

where the marginal $\operatorname{costs} c(w) / \theta e^{\eta+\omega}$ are a function of the vector of input prices $w$, and $F$ stands for some arbitrary fixed costs. According to Shephard's lemma, labour demands for the old and new products can be written as:

$$
L_{1 t}=c_{w_{L}}\left(w_{1 t}\right) \frac{Y_{1 t}}{\theta_{1 t} e^{\eta+\omega_{1 t}}} \quad \text { for } \quad t=1,2
$$

and

$$
L_{22}=c_{w_{L}}\left(w_{22}\right) \frac{Y_{22}}{\theta_{22} e^{\eta+\omega_{22}}} \quad \text { if } Y_{22}>0 \text { and } L_{22}=0 \text { otherwise }
$$

where $c_{w_{L}}($.$) represents the derivative of c($.$) with respect to the wage. Notice that these$ expressions show that employment is correlated with the individual productivity effects $\eta$ and productivity shocks $\omega$. To proceed, we also make the simplifying assumptions that $c_{w_{L}}\left(w_{11}\right)=$ $c_{w_{L}}\left(w_{12}\right)=c_{w_{L}}\left(w_{22}\right)$. This holds approximately, for example, in the likely case where the relative prices of inputs remain roughly constant in the two years and equal for old and new products. $^{13}$

We can decompose the growth of employment between the two years $t=1$ and $t=2$, into the growth of employment due to production of the old products and the growth of employment due to production of the new products, in the following way:

$$
\frac{\Delta L}{L}=\frac{L_{12}+L_{22}-L_{11}}{L_{11}}=\frac{L_{12}-L_{11}}{L_{11}}+\frac{L_{22}}{L_{11}} \simeq \ln \frac{L_{12}}{L_{11}}+\frac{L_{22}}{L_{11}}
$$

where by convention the rate of growth of new products is defined as $L_{22} / L_{11}$, and where we also use a logarithmic rate of growth of the old product to derive the more simple linear equation (1) below in terms of the relevant variables. Based on this decomposition and the labour demand equations with our simplyfying assumptions, we can write the following employment growth equation where the individual fixed effects $\eta$ are differentiated out:

$$
\frac{\Delta L}{L} \cong-\left(\ln \theta_{12}-\ln \theta_{11}\right)+\left(\ln Y_{12}-\ln Y_{11}\right)+\frac{\theta_{11}}{\theta_{22}} \frac{Y_{22}}{Y_{11}}-\left(\omega_{12}-\omega_{11}\right)
$$

\footnotetext{
${ }^{13}$ Notice that $c($.$) is homogeneous of degree one in input prices and hence the derivative c_{w_{L}}($.$) is homo-$ geneous of degree zero. The constancy of relative input prices for old products in the two periods and the equality of input prices for old and new products in the second period thus imply that $c_{w_{L}}($.$) is unchanged$ even if prices change.
} 
Equation (1) is a simple expression which accounts for the observed employment growth in terms of four components: i) the change in efficiency in the production process for the old products; ii) the rate of change of the demand for these products over time; iii) the expansion in production attributable to the demand for new products, and iv) the impact of productivity shocks.

The increase in efficiency of the production of old products $\left(\ln \theta_{12}-\ln \theta_{11}\right)$ is expected to be larger for firms which introduce process innovations in producing them, even if firm efficiency is also expected to grow over time for other important reasons such as learning and spillover effects. The impact of product innovation on employment growth depends on the ratio $\left(\theta_{11} / \theta_{22}\right)$ of the relative efficiency of producing old and new products. If new products are produced more efficiently than old products, this ratio is less than unity and employment does not grow one-for-one with the growth in output accounted for by new products.

\subsection{Econometric model and effects of theoretical interest}

Equation (1) can be rewritten as the following econometric regression:

$$
l=\alpha_{0}+\alpha_{1} d+y_{1}+\beta y_{2}+u
$$

where $l$ stands for the rate of employment growth over the period (i.e., between the year $t=1$ and $t=2), y_{1}$ and $y_{2}$ are the corresponding rates of output growth of old and new products (i.e., $\ln Y_{12}-\ln Y_{11}$ and $Y_{22} / Y_{11}$, respectively), and $u=-\left(\omega_{12}-\omega_{11}\right)+\xi$ is an overall random disturbance where $\xi$ represents miscellaneous (uncorrelated) errors. The parameter $\alpha_{0}$ represents (minus) the average efficiency growth in production of the old product, and a binary variable $d$, equal to one if the firm has implemented a specific process innovation not associated with a product innovation, picks up the effects of such "process innovation only" through parameter $\alpha_{1} \cdot{ }^{14}$ The parameter $\beta$ captures the relative efficiency of the production

\footnotetext{
${ }^{14}$ We can extend equation (2) to allow process innovation to affect changes in the efficiency of production of old and new products as follows:

$$
l=\left(\alpha_{0}+\alpha_{1} d_{1}\right)+y_{1}+\left(\beta_{0}+\beta_{1} d_{2}\right) y_{2}+u
$$

where $d_{1}$ and $d_{2}$ are binary variables equal to one if the firm implemented process innovations respectively related to the production of old and new products. In practice, however, when a firm declares both process and product innovations, we cannot separate process innovations that relate to their old products and their new ones. We nonetheless have experimented with various alternatives: see the additional regressions shown
} 
of old and new products. Notice that the variable $y_{1}$ has a coefficient equal to one and can thus be substracted from $l$ on the left-hand side of the equation for estimation. ${ }^{15}$

Equation (2) identifies two effects of major interest. Being able to measure the growth of output due to the introduction of new products, it allows us to estimate the gross effect of product innovation on employment, while the observation of process innovations related to the production of old products allows us to estimate the gross productivity or "displacement" effect of process innovation. However, equation (2) also has obvious limitations. In fact, this variable embodies three different employment effects which cannot be separated without additional (demand) data: i) the possible "autonomous" increase in firm demand for the old products (for example, due to cyclical or industry effects); ii) the "compensation" effect induced by any old product price decrease following a process innovation; and iii) the cannibalization of old product demand resulting from the introduction of new products either by the firm or by its competitors.

In what follows, we shall now discuss in detail the problems involved in the identification and estimation of parameters of equation (2).

\subsubsection{Identification issues}

Identification and consistent estimation of the three parameters of interest $\left(\alpha_{0}, \alpha_{1}\right.$ and $\left.\beta\right)$ of equation (2) depend on the lack of correlation between the variables representing process and product innovations ( $d$ and $y_{2}$ ) and the error term $u$ or, at least, on the availability of instruments correlated with these variables and uncorrelated with $u$.

Innovations are the result of the success of "technological investments", mainly R\&D, which have to be decided by firms in advance and depend on their individual productivity effects $\eta$. Therefore, innovations are likely to be correlated with these effects. They are, however, differentiated out in equation (2) and do not enter into $u$. The unobserved productivity shocks $\omega$ remain in $u$, and their correlations with $d$ and $y_{2}$ depend on the assumptions which can

in the Appendix A.

\footnotetext{
${ }^{15}$ Equation (2) can also be rewritten and reinterpreted in terms of a productivity growth equation by simply rearranging it as follows:

$$
y_{1}+y_{2}-l=-\alpha_{0}-\alpha_{1} d+(1-\beta) y_{2}-u
$$

showing that labour productivity will depend positively on process innovation (recall $\alpha_{1}$ is likely to be negative) and on product innovation if $\beta$ is less than one.
} 
reasonably be made about both their characteristics and the timing of the firm's technological investments.

If the firm is supposed to make its technological investment decisions in advance and the shocks are considered unpredictable, innovations will not be correlated with $\omega$ and $u$ and an OLS estimator would suffice to estimate equation (2) consistently. ${ }^{16}$ On the contrary, if firms are assumed to make these investments within the period affected by the shocks $\omega$, the resulting innovations will be correlated with these shocks, even if they were unpredictable before. In this case, however, lagged values of the included variables could be considered uncorrelated with $\omega$ and $u$ and used as valid instruments. Finally, if $\omega$ is assumed to be autocorrelated, the timing of the investment decisions becomes irrelevant because the current value of $u$ depends on its past values and innovations will likely be correlated with past values of $u$ as well as with its current value. In this case, both $d$ and $y_{2}$ and their past values are endogenous and identification should rely on the use of (external) instrumental variables which can be claimed to be exogenous with respect to $\omega$.

However, let us make a series of general considerations about the identifiability of the model. Firstly, there are good reasons in fact to think that productivity shocks are not predictable or very badly predictable by firms at the moment of deciding and starting their technological investments; hence, consistent estimation of model (2) by OLS is not too unlikely. For example, it seems rather unrealistic to assume that firms can forecast their future labour or organizational problems or demand shocks when deciding $R \& D$ investments, which to a large extent are made well in advance of the innovations they eventually generate.

On the other hand, if technological investments were positively related with the productivity shocks $\omega$ (e.g., if they are stimulated by an anticipated burst in firm capacity utilization and the resulting increase in labour productivity), and hence negatively with the overall error $u$, we will expect a downward bias in the coefficients of $d$ and $y_{2}$. In other words, we would estimate employment displacement effects of process innovation that are too large and an impact of the introduction of new products that is too low. As we will see, our estimates seem basically free of such biases after controlling for the remaining problems (see next section) and using our instrumental variables.

Finally, while our data base allows us to make only a very limited use of lagged values

\footnotetext{
${ }^{16}$ This is the basic timing assumption of models in the espirit of Olley and Pakes (1996), like Levinsohn and Petrin (2003) or Doraszelski and Jaumandreu (2007).
} 
of innovation or related variables, it fortunately includes some variables which indicate the reasons for the introduction of innovations and can be convincingly contemplated as a priori unrelated to the productivity shocks $\omega$ (see subsections 3.4 and 5.1).

\subsubsection{Measurement problems}

To estimate equation (2), however, we have to face another difficult issue. In this equation, we must substitute the growth in nominal sales, which is what we observe, for the growth in real production. The problem that prices are unavailable at the firm level to deflate changes in nominal sales is in fact common in nearly all firm productivity data analyses. This problem is particularly relevant here, since we are attempting to estimate the relative efficiency of producing old and new products, which may be sold at different prices. ${ }^{17}$ Denoting $g_{1}=$ $\left(\frac{P_{12} Y_{12}-P_{11} Y_{11}}{P_{11} Y_{11}}\right)$ as the nominal growth rate of sales due to old products, we can approximately write $g_{1}=y_{1}+\pi_{1}$, where $\pi_{1}=\left(\frac{P_{12}-P_{11}}{P_{11}}\right)$ is the rate of increase of the prices of old products. Similarly, but taking into account that $Y_{21}=0$, we can define $g_{2}=\left(\frac{P_{22} Y_{22}}{P_{11} Y_{11}}\right)$ as the nominal growth in sales that is due to new products and write $g_{2}=y_{2}\left(1+\pi_{2}\right)=y_{2}+\pi_{2} y_{2}$, where $\pi_{2}=\left(\frac{P_{22}-P_{11}}{P_{11}}\right)$ is the proportional difference of the prices of new products with respect to the prices of the old products. Substituting $g_{1}$ and $g_{2}$ for $y_{1}$ and $y_{2}$ in equation (2), and moving $g_{1}$ to the left-hand side of the equation, we obtain:

$$
l-g_{1}=\alpha_{0}+\alpha_{1} d+\beta g_{2}+v
$$

where the new unobserved disturbance is now $v=-\pi_{1}-\beta \pi_{2} y_{2}+u$. In case of a non-zero mean of $\pi_{1}$, the model will include $-E\left(\pi_{1}\right)$ in the intercept and $-\left(\pi_{1}-E\left(\pi_{1}\right)\right)$ in the disturbance.

To estimate the parameters of (3) consistently, we have thus to take into account two additional problems. ${ }^{18}$ Firstly, $g_{2}$ (i.e., $y_{2}+\pi_{2} y_{2}$ ) is going to be correlated with the composite error term $v$ (i.e., $-\pi_{1}-\beta \pi_{2} y_{2}+u$ ). We hope that this only happens because $\pi_{2} y_{2}$ is obviously

\footnotetext{
${ }^{17}$ We can assume that the old and the new products are "differentiated" enough so that they have their own interrelated downward sloping demand curves. That is, in the first period $Y_{11}=D_{11}\left(p_{11}, z_{1}\right)$, and in the second period the demand system is $Y_{12}=D_{12}\left(p_{12}, p_{22}, z_{2}\right)$ and $Y_{22}=D_{22}\left(p_{12}, p_{22}, z_{2}\right)$, where $z_{1}$ and $z_{2}$ stand for firm-specific, or even product-specific, exogenous demand shifters. The equilibrium prices will in general depend on the degree of differentiation of the new and old products as embodied in the demand functions. However, we do not need to explicitly model these demand functions because our exercise is based on conditional labour demands. We simply assume that the firm produces the equilibrium quantities $\left(Y_{11}\right)$ and $\left(Y_{12}\right.$ and $\left.Y_{22}\right)$ demanded in the first and second periods, respectively.

${ }^{18}$ We should also note that the growth rates $g_{1}$ and $g_{2}$ are not observed directly, but that they are constructed
} 
correlated with $\beta \pi_{2} y_{2}$, and that the term $y_{2}$ is uncorrelated with both $\pi_{1}$ and $\beta \pi_{2} y_{2} \cdot{ }^{19}$ If this condition is met, the problem amounts to finding an instrumental variable for $g_{2}$ that is correlated with the real ratio $y_{2}$ and uncorrelated with $\pi_{2} y_{2}$. We discuss such a possible instrument in subsections 3.4 and 5.1 below. Notice that the likely bias in $\beta$ in the absence of instrumentation is an "attenuation" bias.

Secondly, the composite error term $v$ includes $\pi_{1}$ as long as we cannot control for the change in the prices of the old products. This creates a problem for isolating one of the structural effects of interest. We know that any increase in efficiency decreases marginal cost by the same proportion. Therefore, if firms are pricing their products competitively or by setting a markup on marginal cost, price variations are likely to be proportional to the efficiency increase (with an opposite sign). If we suppose, for example, that the price change $\pi_{1}$ depends on the marginal cost change $c$ according to the rule $\pi_{1}=\pi_{0}+\gamma c$, where $\pi_{0}$ is a constant and $\gamma$ is the pass through parameter (with $0<\gamma<1$ ), and that marginal cost changes themselves are related to process innovation efficiency gains according to $c=\alpha_{1} d$, we can write that $\pi_{1}=\pi_{0}+\gamma \alpha_{1} d$. Thus, in equation (3), we will only be able to estimate an attenuated effect $(1-\gamma) \alpha_{1}$. In other words, in the absence of firm price information, we can only identify an effect of process innovation on employment net of (direct) compensating price variations. As such compensating movements can be important (with $\gamma$ close to 1), we could even find that process innovation has no effect on employment.

To deal as best as we can with this latest problem in our econometric analysis, we take the corresponding industry price indices $\pi$ as a rough proxy for $\pi_{1}$, available at a more or less on the basis of observations of the share $s$ of new products in total sales in the second period and the growth rate of total sales $g$ between the two periods as $g_{2}=s(1+g)$ and $g_{1}=g-s(1+g)$ (see Appendix B). One may then wonder about the effect of having a variable that is likely to be measured with error on both sides of the estimating equation. Supposing that $s=s^{*}+\varepsilon$, where $s^{*}$ is the true share and $\varepsilon$ is white noise (as in the standard case of random measurement errors in variables), and substituting $s$ for $s^{*}$ shows that $g_{2}$ will be correlated with an error component $(1-\beta) \varepsilon(1+g)$ in equation (3). The potential error in variables bias is hence likely to be small and to fade away with the instrumentation of $g_{2}$.

${ }^{19}$ Technically, $y_{2}$ will be uncorrelated with $\pi_{2} y_{2}$, if $y_{2}$ and $y_{2}^{2}$ are uncorrelated with $\pi_{2}$, or more generally if $\pi_{2}$ is mean independent of $y_{2}$ (i.e., $E\left(\pi_{2} \mid y_{2}\right)=0$ ). This entails that the change of the prices of the new products with respect to the prices of the old products $P_{22} / P_{11}$ is not a function of the ratio of the new products to the old products $Y_{22} / Y_{11}$. With many unrelated factors influencing the new prices (quality improvement or degradation, substitutability among goods, demand shifters, market power, etc.) this is a reasonable assumption. 
detailed industry classification and assigned to firms according to their main activities (see Appendix B for some precisions). Therefore, in practice we use $l-\left(g_{1}-\pi\right)$ as the dependent variable, which will leave the term $-\left(\pi_{1}-\pi\right)$ in the error term. We may hope that, to the extent the firm prices do not deviate much from industry prices, this adjustment at least partly corrects the attenuation bias in the estimated $\alpha_{1}$.

\subsection{Estimation strategy}

In summary, to consistently estimate the parameters of interest in our model, we have to address the endogeneity problem created by the possible correlation of $y_{2}$ with productivity shocks and by its necessary replacement by $g_{2}$ for lack of firm-level price information, and we have to consider that $d$ could also be correlated with productivity shocks. Our strategy thus relies on the choice of instrumental variables that can be considered to be uncorrelated with both the price differences and the productivity shocks. After some trials, we settled on what we thought a priori the most appropriate instrument we could consider, but we also used it in conjonction with two other appropriate instruments (see the detailed discussion of these issues in subsections 5.1 and 5.2).

\section{Innovation and employment across four countries}

In this section, we present descriptive statistics and discuss the results of the initial exploration of the data. The sizes of the national samples differ, but all samples are representative by industry-size strata. Overall representativeness, however, can diverge across countries, and therefore comparisons must be considered with due care. Details on the samples and variable definitions can be found in Appendix B. Tables 2a and 2b present descriptive statistics respectively for the manufacturing and service sector in the four countries. ${ }^{20}$ For each variable, the sample is split into three sub-groups according to whether the firm reports that, over the whole study period 1998-2000, it has not introduced any innovation, has introduced only process innovations, or has introduced product innovations. We do not distinguish firms that have introduced both product and process innovations from those that only introduce product innovations, since we cannot know not from the data whether these two types of

\footnotetext{
${ }^{20}$ See Appendix Table B1 for a description of the industry composition of the manufacturing and service sectors samples.
} 
innovations are related or not.

Table 2a shows that innovators represent between about $40 \%$ (for the UK) and $60 \%$ (for Germany) of manufacturing firms in the four countries, and that about more than three fourths of them have introduced product innovations (half of them together with process innovations). Employment growth of innovators is consistently higher than that of noninnovators across the four countries, with the employment growth for product innovators being slightly higher than for process innovators only. Productivity gains also tend to be higher in the innovating firms (with the exception of Spain, where there is almost no difference in average productivity growth between innovators and non-innovators). Notice that the increase in employment in innovative firms is higher despite their larger labour productivity gains. This shows that, on average, the effects stemming from the growth of output dominate the displacement effects of innovation. Although all output effects do not necessarily come from innovation, this suggests that the compensation effects of innovation are likely to be important.

The average increase in sales over the period 1998-2000 is high in all countries, reflecting both an expansionary phase of the industrial cycle and the fact that we are considering samples of continuing firms. Average sales growth is highest for Spain, even when deflated with the corresponding rate of price increase, which is also highest. At the time, the Spanish economy was experiencing a particularly rapid overall growth. Sales growth is consistently higher for innovators than for non-innovators, with no systematic difference between firms that only introduce process innovations and those that introduce product innovations. For product innovators, sales of new or significantly improved products introduced during the period 1998-2000 are a very important component of total sales growth: these sales in 2000 (i.e., $Y_{22}$ ) amount to more than one third of sales of old products in 1998 (i.e., $Y_{11}$ ) for the German, Spanish and British firms, and to nearly $20 \%$ for the French firms. Sales of new products appear to cannibalise sales of old products to a different extent in the four countries. $^{21}$

Table $2 \mathrm{~b}$ for the service sector shows that the proportion of innovators is lower in the four countries than in manufacturing, but relatively high in Germany and particularly low in the

\footnotetext{
${ }^{21}$ Note, however, that the fact that average growth in sales of unchanged products is negative for product innovators does not necessarily imply cannibalisation of old products by new products. For example, it is possible that firms whose traditional markets are declining are more likely to introduce product innovations.
} 
United Kingdom and Spain. However, in the four countries, the proportion of innovators that only introduce process innovations is slightly higher than in manufacturing. It is also the case that in all four countries employment growth is somewhat higher for innovators, and higher for product innovators than for only process innovators. This suggests that increase in demand associated with new services plays as important a role in employment creation in the service sector as in manufacturing. The productivity growth of innovators is, however, sometimes higher (France, Spain) and sometimes equal or lower (Germany, UK) than the productivity growth of non-innovators.

The growth of nominal sales during the three years 1998-2000 is even higher than in manufacturing, but the average price increases are also higher. As with employment growth, sales growth is higher for product innovators, but in this case less for firms that only introduce process innovations. For product innovators, sales of new products are as large a part of total sales growth as in manufacturing, although it seems that cannibalisation of old products by new products may be slightly less.

To summarize, data across the four countries show that employment grows more in innovative firms, and more intensely in firms with product innovations than in firms with process innovations. For the firms with product innovations, the demand for the old products always decreases, but the increase in sales of new products surpasses this decrease (i.e., new products contribute to an increase in demand). All this suggests that compensation effects of all kinds are prevalent, and that there is no hope to assess the relative roles played by process and product innovations without estimating a model as the one we consider here.

\section{Econometric results}

\subsection{Basic specification}

Table 3 presents the results of estimating the basic specification of our model, which is equation (3), by OLS and by IV, using the increased range indicator as our preferred instrument for the sales growth due to new products variable. The dependent variable is employment growth minus the growth of sales due to the unchanged products. As discussed above, we control for changes in the prices of old products by deducting an industry price growth index from the nominal sales growth of unchanged products (i.e., the dependent variable is $\left.l-\left(g_{1}-\pi\right)\right)$. The value of the constant is therefore an estimate (with a negative sign) of the 
average real productivity growth in the production of old products for the two-year period 1998-2000. In all regressions we include a full set of industry dummies, but their coefficients are constrained to add up to zero in order to preserve the interpretation of the constant. ${ }^{22}$ The key explanatory variables are the process innovation only dummy $d$ and sales growth due to new products $g_{2}$ variables. Let us first discuss in detail the results for manufacturing and then more briefly the corresponding results for services. In the next subsection, we use other possible instruments in addition to our preferred one, we test for their joint validity, and for the endogeneity of the process innovation only variable. Other robustness checks are discussed in Appendix A. ${ }^{23}$

Panel A of Table 3 gives the OLS estimates for manufacturing in the four countries. The constant $\alpha_{0}$ of the regression shows sensible average productivity growth for each country, which implies constantly decreasing employment for a given old products ouput. Recall that a negative coefficient $\alpha_{1}$ in the process innovation only indicator represents an additional increase in productivity (and thus a displacement of labour) in the production of old products. The coefficient is negative and significant for Germany and the UK. The coefficient is negative but insignificant for France, and positive but insignificant for Spain. These last two estimates could be due to a larger pass through of productivity improvements in prices imperfectly picked up by our industry price indices. ${ }^{24}$ Also recall that the estimated coefficient $\beta$ of sales growth due to new products is an estimate of the relative efficiency of the production process for new products compared with that for old products. The fact that the coefficient is significantly less than one for all countries would suggest that new products are produced more efficiently than old products. However, as discussed above, any endogeneity (due to unobserved price changes or correlation with the non-technological productivity shocks) is likely to produce a downward bias in this coefficient, overstating the productivity gains associated with the production of new products.

Panel B thus reports on our IV estimates, taking the sales growth due to new products

\footnotetext{
${ }^{22}$ Firm size dummies, when included, turned out in general to be not significant, and did not practically affect our results.

${ }^{23}$ In particular, we report "naive" exploratory OLS results in Appendix Table A2. These results do not, as in equation (3), impose the theoretical constraint that the coefficient of $\left(g_{1}-\pi\right)$ equals one. We also report IV estimates of equation (3) for two variants of the specification of process innovation in Appendix Table A3 and comment other regressions.

${ }^{24}$ This seems particularly likely for Spain, where prices have been increasing faster than in the other countries during the period.
} 
variable as endogenous and using a single instrument (i.e., the equation is exactly identified). Any valid instrument must be related to growth in sales of new products but not to any change in the price of new products compared to old products and to productivity shocks. Among the possible variables we could use, the one we preferred was the increased range of goods and services indicator, which assesses the impact of innovation on the increase in the range of goods and services produced by firms, as reported by them in the common CIS questionnaire for the four countries. The variable is coded as zero if innovation is not relevant for the range of goods and services produced, one if the impact of innovation on the range is low, two if it is medium and three if it is high. ${ }^{25}$ Two other related questions ask the firm about the impact of innovation for an increased market share and that for improved quality in goods and services, so that the increased range of goods and services variable must be interpreted as a measure of the extent to which the firm's innovation is associated with an increase in demand for reasons other than changes in product prices and quality. As a result, we expect this instrument to be uncorrelated with changes in the price of new products compared to old products. It also seems unlikely that it is correlated with productivity shocks. We also verify that in practice it will not be a weak instrument since it appears to be clearly positively and significantly correlated with the endogenous variable in the first-stage reduced form regressions for the four countries. ${ }^{26}$

The IV estimates of the constant and the process innovation only dummy change noticeably from the OLS ones, showing faster average productivity growth (and corresponding decrease in employment) in the production of old products and suggesting smaller improvements in productivity (and employment) due to process innovation in Germany and the UK. But the most notable result is that the IV estimates of the coefficient $\beta$ of sales growth due to new products are higher than the OLS estimates, which is consistent, as expected, with the correction of the downward biases related to endogeneity and price mismeasurement. All the IV estimated $\beta$ are extremely close to one, now showing no evidence that new products are produced with higher efficiency than old products, that is, no evidence of productivity gains and employment displacement effects associated with product innovation.

\footnotetext{
${ }^{25}$ We have experimented with a more flexible form of this variable, but this step variable appears to fit the data remarkably well, with very little evidence of any non-linear effect in the reduced form equation.

${ }^{26}$ In France, Germany, Spain and the UK, the R-squared statistics obtained in these first-stage regressions are respectively equal to $0.39,0.20,0.35$ and 0.28 , and the corresponding coefficients on the increased range equal to $5.3,10.5,11.2$ and 14.5 , with t-statistics of $30.8,15.8,26.9$ and 16.0.
} 
Turning now to services, we have to consider their results with particular caution (as was suggested in subsection 2.1). In addition, we have to take into account the following two differences with respect to what we were able to do for manufacturing. First, in spite of the great heterogeneity of service activities, we were able to use only an overall price deflator in France and Spain, and in Germany and the UK price deflators are available at a very high level of aggregation. Secondly, the proportion of innovating firms in services is much lower than in manufacturing, particularly so in Spain and the UK, which can largely affect the precision of the estimates. Despite these caveats, the results we obtain, shown in Panels C and D of Table 3, look interesting. Average productivity growth in production of the old product, as revealed by the constant term, is higher than in manufacturing for France, lower in Germany and Spain, and about the same in the UK. Not too surprisingly, process innovation only is not significant in any country. And, as in manufacturing, the coefficients on sales growth due to new products are less than one in the OLS case (particularly in Germany), but augment to become insignificantly different from one in all four countries when estimated by IV, using the increased range variable as an instrument. We cannot thus reject the hypothesis that new products are, on average, produced with the same productivity as old products, although there is some slight indication that new products could be produced with lower productivity in France (with an estimated coefficient $\beta$ of 1.15 statistically different from 1 at the $10 \%$ level of confidence).

\subsection{Testing endogeneity}

The consistency of our IV estimates of equation (3) in Table 3 is supported by the a priori likelihood of the exogeneity assumptions about our preferred instrument, as well as our use of a growth rate specification which differences out the fixed effects. It is also important that all coefficient changes obtained by instrumenting the equation go in the direction expected when correcting for the endogeneity biases, and lead to estimates of reasonable magnitude. Here we provide some additional statistical evidence for the consistency and robutness of our results.

We looked for other potential instruments in addition to the increased range variable. We thought that a similar variable based on the answer of the firms to the CIS question on the importance of clients or customers as a source of information for innovation (clients as a 
source of information), and the indicator of continuous R\&D investment during in 1998 to 2000 (continuous RED engagement) were a priori valid and should be well correlated with both the sales growth due to new products variable $g_{2}$ and the process innovation only variable $d .{ }^{27}$ Using these three variables as instruments provides two overidentifying restrictions if we maintain the assumption that $d$ is exogenous, and one restriction if we consider that this variable is also endogenous. We use them to test for the overidentifying restrictions by means of a $\chi^{2}$ test (Sargan test). This provides us with an indicator of the validity of the employed instruments. Then, we use them to test for the exogeneity assumption maintained until now on $d$ by means of a difference in the $\chi^{2}$ tests ("difference-in-Sargan" test). ${ }^{28}$

Panel $\mathrm{A}$ in Tables 4a and 4b for manufacturing and services, respectively, present the IV estimates of equation (3) using the three instruments for $g_{2}$ and performing the two Sargan tests of overidentifying restrictions. The overall Sargan test does not reject the joint validity of the three instruments with high degree of confidence for all four countries in manufacturing and services. The difference-in-Sargan test does not reject the exogeneity of $d$, again with high degree of confidence. The statistical evidence thus provided confirms our previous IV estimates in Panels B and D of Table 3 (assuming exogeneity of $d$ and instrumenting $g_{2}$ by the increased range variable only).

However, such confirmatory evidence is only as good as the discriminatory capacity of the Sargan tests. To have a feeling of whether such discriminatory power could be weak, we have also estimated equation (3) using a much more doubtful set of instruments, and computed the corresponding overall Sargan tests. To the increased range instrument, we add the importance of innovation for the improvement of the quality of the product and the increase of the firms' market share (improved quality and increased market share), and innovation effort (ratio of $\mathrm{R} \& \mathrm{D}$ and other innovation expenditures to sales). A product quality improvement is likely to be associated with a price increase, an increase in firm market share can follow from a

\footnotetext{
${ }^{27}$ The overall $R$-square of the first-stage regressions of the sales growth due to new products on the set of the three instruments are respectively equal to $0.41,0.46,0.39$ and 0.37 in manufacturing for France, Germany, Spain and the United Kingdom, and, similarly, to 0.36, 0.42, 0.38 and 0.45 in services.

The F statistics of the regressions of the process innovation only variable on the set of the three instruments are 36.6, 3.5, 61.4 and 23.6 in manufacturing, and 24.7, 5.9, 27.8 and 7.8 in services.

${ }^{28}$ The overall Sargan test evaluates the appropriate scaled value of the objective function at the optimum. The "difference-in-Sargan" test measures the change in the appropriately scaled value of the objective function when the assumption of exogeneity of $d$ is maintained and when it is dropped.
} 
price reduction resulting itself from some process improvement, and a change in the firm innovation effort may be rapidly decided in reaction to important productivity shocks. The results, shown in Panel B of Tables 4a and 4b, are clear. The overall Sargan tests clearly reject the validity of this alternative set of instruments at a $1 \%$ and $5 \%$ level of significance in Germany and Spain, respectively, for manufacturing and at 1\% in France and the United Kingdom for services and a $5 \%$ level of significance for German services. This again, but this time a contrario, supports our choice of the increased range variable as an appropriate instrument.

Finally, it is of interest to present one last piece of evidence for the same conclusion, even if for only one country. The instruments that we are able to use pertain to the year 2000 or the period 1998-2000, and are therefore contemporaneous to $g_{2}$. A particularly appropriate choice of instruments under some circumstances discussed above would be that of lags of a variable like firms' innovation or R\&D effort. Unfortunately, such information was not available from the CIS3 data alone, and we have only been able to get it in the case of German manufacturing. Column $\mathrm{C}$ of Table 4a shows the results we obtain in this case, using lagged $R \& D$ effort as another instrument in addition to the increased range variable. The Sargan test does not reject, with a very high degree of confidence, that the two variables can be taken as alternative valid instruments.

\section{An employment growth decomposition}

An interesting way to summarise the evidence obtained with our estimates is to use them to decompose the four country employment growth average, over the two year study period 1998-2000, into four different components. Using our preferred specification, we can write employment growth for each firm in the following way:

$$
l=\sum_{j}\left(\widehat{\alpha}_{0}+\widehat{\alpha}_{0 j}\right) i n d_{j}+\widehat{\alpha}_{1} d+\left[1-1\left(g_{2}>0\right)\right]\left(g_{1}-\pi_{1}\right)+1\left(g_{2}>0\right)\left(g_{1}-\pi_{1}+\widehat{\beta} g_{2}\right)+\widehat{u}
$$

with the same notations as before and with $i n d_{j}$ denoting the industry dummies and $\widehat{\alpha}_{0 j}$ their estimated coefficients. For a given firm, the first component $\left(\sum_{j}\left(\widehat{\alpha}_{0}+\widehat{\alpha}_{0 j}\right) i n d_{j}\right)$ measures the change in its employment attributable to the (industry specific) productivity trend in production of old products; the second component $\left(\widehat{\alpha}_{1} d\right)$ estimates the change in employment associated with the gross productivity effect of process innovation in the production of old 
products; the third one $\left(\left[1-1\left(g_{2}>0\right)\right]\left(g_{1}-\pi_{1}\right)\right)$ corresponds to the employment change associated with output growth of old products for firms that do not introduce new products; and finally, the fourth one $\left(1\left(g_{2}>0\right)\left(g_{1}-\pi_{1}+\widehat{\beta} g_{2}\right)\right)$ gives the net contribution of product innovation (i. e., contribution after allowing for any substitution of new products for old products). The last term $(\widehat{u})$ is a zero-mean residual component.

Table 5 reports the application of this decomposition to the eight samples of manufacturing and services firms in the four countries, using the proportions and averages from Table 2a and Table $2 \mathrm{~b}$ for each sample, and the regression IV estimates from Panel B and Panel D in Table 3. Notice that for each sample the average residual component is equal to zero, and thus the productivity trend in the production of old products can be obtained by subtracting the sum of the other components from the average employment growth.

First considering manufacturing, Table 5 shows that incremental productivity improvements in the production of existing products are an important source of reductions in employment requirements for a given level of output. The effect is smallest in France $(-1.9 \%$ over two years) and largest in Germany (-7.5\% over two years). However, growth in output of existing products over this expansionary period more than compensates for the productivity effect in all countries except Germany.

Individual process innovations account for only small employment changes in all countries, generally resulting in a small displacement effect. This can be partly because process innovation effects are in practice somewhat underestimated, but also because the number of firms that introduce only process innovations is small. Employment reductions resulting from process innovations may indeed be important for individual firms, but they amount to only a small fraction of overall employment changes.

In contrast, product innovations play an important role in stimulating firm-level employment growth. The decomposition shows that the effect of new product sales, even net of the cannibalisation of old products, is sizeable in all countries. It implies an average firm-level employment increase over the period ranging from $4.8 \%$ in the UK to $8.0 \%$ in Germany. ${ }^{29}$

Overall, the importance of innovation for firm-level employment growth becomes clear when the different sources of employment change are compared. In Germany, where the combined

\footnotetext{
${ }^{29}$ Peters (2008) estimates the employment effects of innovation in Germany for the recession period 20002002. Though the magnitude of the effects she finds are smaller, the overall conclusions remain similar: in particular the net contribution of product innovation accounts for large part of employment growth.
} 
effect of growth in existing output and trend productivity increases in the production of existing products is slightly negative, product innovation is responsible for more than the whole average firm-level employment growth during the period. Even in Spain and the UK, where the growth of sales of old products is responsible for a large proportion of net employment growth, product innovation is on average more important than the net effect of growth in sales of existing products.

Looking next at the corresponding results for services, they appear somewhat different. Average within-firm employment growth is almost double that in manufacturing during the period, and more than double in the UK. On average, product innovation accounts for a smaller proportion of total employment growth than in manufacturing, but still non-negligible. In Spain and the UK, the main source of firm-level employment growth is growth in the production of old products, with a small counterbalancing effect of trend productivity increases only in the UK. In France, the contribution of product innovation is roughly the same as the net contribution of the growth of sales of existing products. Total employment growth is lower in Germany, and growth in the production of new products accounts for a share of employment growth that is larger in Germany than in the other countries.

Keeping in mind the limitations of the analysis stressed in section 3.3, the decomposition given in Table 5 can be read as a simple but effective way to show what our estimates say about the average effect of firm innovation on employment. In short, we find that process innovations only tend to have a negligible effects on employment, because we measure weak displacement effects and because they affect few firms (when not associated with product innovations). On the contrary, productivity trends, which correspond to general sources of technical progress other than firms' own innovations, result in important displacement effects on employment in services and even larger ones in manufacturing. However, the effects that can be attributed to the growth of sales of new products appear strong enough to more than compensate for these effects. The implication is that employment would have shown small positive rates of growth almost everywhere, even if the demand for old products had suddenly stopped growing. Overall, the net contribution of product innovation to employment growth for the two-year period $1998-2000$ is in the $5 \%$ to $8 \%$ range, which is quite impressive. 


\section{Concluding remarks}

Understanding the relationship between innovation and employment at the micro level is essential for predicting how innovation might affect employment, and hence for the effective design of innovation policy together with other policy interventions. In this paper, we have derived a simple formal model of the firm-level relationship between innovation and employment growth, and we have estimated it by using a source of comparable and representative data on innovation in manufacturing and services firms across four European countries. Our results shed new light on the relative roles of displacement and compensation effects of product and process innovation on employment growth in manufacturing. They also provide an insight into this relationship in services.

Our results, however, are only a first step in the analysis in at least three important respects. First, the lack of data to model the demand side of firms' activity imposes some obvious limitations when estimating the displacement and compensation effects of innovation. In particular, "business stealing" effects cannot be separately identified from pure market expansion, and compensation effects resulting from price pass-through cannot be fully assessed. Secondly, we have considered only the total level of employment and not its composition in terms of skills or types of worker. For example, our results suggest that workers on average have little to fear from product innovation, but we have not been able to address the possibility that new products are more complementary to skilled than to unskilled workers. Thirdly, our results do not relate directly to aggregate employment growth, since we do not observe nor explain why firms enter and exit from our samples, nor do we consider why and how firms innovate and grow. All these topics represent important lines of research at the micro level and suggest high returns to increasing the richness of available data sources.

In spite of their limitations, our findings are interesting. They reveal that, in manufacturing, although process innovation tends to displace employment, compensation effects are prevalent, and product innovation is associated with employment growth. The destruction of jobs through process innovation, as well as being relatively infrequent, seems to be weak. At the same time, we observe no evidence of displacement effects associated with product innovation, and compensation effects resulting from the introduction of new products imply employment growth even when the cannibalisation of old products is taken into account. In the service sector, we find no evidence of displacement effects from process innovation, and 
the growth in sales of new products, although relatively less important than in manufacturing, accounts for a non-negligible proportion of employment growth. These results agree well with the already existing and provide explanations for both the strong positive effect of product innovation on employment and the inconclusive or fragile effects of process innovation that have usually been found.

Overall, the results are similar across countries, although there emerge some interesting differences, which might also merit further investigation, probably by extending our analysis to different periods when possible. For example, we find no evidence for a displacement effect of process innovation in Spanish manufacturing, possibly due to greater pass-through of productivity improvements in lower prices. Product innovation appears to play a larger role in employment growth in Germany than in the other countries, and possibly a smaller role in the UK, while higher levels of firm-level employment growth over this period in Spain are largely explained by faster growth in output of existing products. 


\section{Appendix A: Additional regressions}

\section{Naive OLS regressions}

OLS descriptive or "naive" regressions for the manufacturing and services samples in each country are presented in Table A1. In each case, employment growth is regressed on deflated total sales growth, dummies for "process innovation only" and product innovation, and a full set of industry dummies.

The coefficient on real sales growth is fairly stable across samples and is a long way below unity in all cases. On face value, this suggests that sales growth is associated with less than one-for-one growth in employment. The coefficient on the "process innovation only" dummy is insignificant in all cases apart from Spanish manufacturing, where it is positive, suggesting a negative correlation between process innovation and productivity growth. Overall, the results are quite uninformative about the relative roles of displacement and compensation effects in the relationship between innovation and employment growth. They mainly show what is gained by imposing more structure on the data using our theoretical model and information about the mix of sales between old and new products.

\section{Alternative process innovation specifications}

Since we do not know whether process innovations refer to the production of old or new products, we considered two extreme alternative specifications of our model. In Panels A and B of Table A2 for manufacturing, and similarly in Panels C and D for services, we respectively present IV estimates for a specification assuming that all the process innovations of product innovators correspond to the production of old products, and for a specification assuming that they all correspond to the production of new products.

The coefficient on the process and product innovation indicator in Panel A for manufacturing is negative and insignificant for Germany and Spain, but positive and marginally significant for France and the UK, apparently suggesting that the process innovations of product innovators are associated with employment growth in production of the old product (or slower productivity growth) after allowing for any price pass-through. However, in both cases, comparing these estimates to our previous ones (in Panel B of Table 3 in the text), we see that, while the coefficient on the process innovation only indicator remains unchanged, 
the coefficient on sales growth due to new products is slightly reduced from about 1.0 to about 0.9 , suggesting lower employment growth associated with production of the new product. The results in Panel $\mathrm{C}$ for services are unchanged from previously, the coefficient for the product and process indicator being insignicant in all four countries, as well as that for the process inovation only indicator.

The other alternative hypothesis that the process innovations of product innovators are in fact associated with production of new products is tested in Panels B and D by including a variable interacting the process and product innovation indicator and the sales growth due to new products variable, thereby allowing the average relative productivity in production of the old and the new products to be different for firms that also introduce process innovations. In this case, as an additional instrument, we use the existing increased range instrument interacted with the process and product innovation dummy. For manufacturing, the estimates correspond closely with those in Panel A, with insignificant negative coefficients on the interacted variable for Germany and Spain, and positive and marginally significant coefficients for France and the UK, suggesting that new products are associated with smaller productivity increases (or larger productivity decreases) for firms that also introduce process innovations. For services, as in Panel C, the estimates in Panel D are unchanged from previously, the coefficients of the interacted variable being insignificant in the four countries.

Overall, given the available data, we are not able to distinguish between the alternative hypotheses embodied in Panels A and $\mathrm{C}$ and in Panels B and D, and the not-too-surprising conclusion is that the truth is very likely in between, with process innovations being associated with both old products and new products. For this reason, our preferred specification is that of Table3 in the main text, where we can be sure that the process innovations of firms that do not introduce new products relate to the old product.

\section{Other regressions}

We have also carried out other regressions to take advantage of the availability of a given variable, sometimes for a single country. These are variables that were not included in the core CIS3 questionnaire, but were added by the relevant statistical agencies in individual countries.

First, in all countries, we included the ratio of physical investment to the value of the sales 
at the beginning of the period (in 1998) as an explanatory variable. Introducing this variable may control for the role of investment in the subsequent growth of employment, and can also be interpreted as an indirect check on the assumption of no changes in relative factor prices. In the case of a change in factor prices, this variable would tend to be significant. We found that the variable was significant for some regressions but the coefficients on process innovation only and sales growth due to new products were not significantly affected.

Secondly, we introduced a variable specific to the German data indicating whether firm process innovations are associated with rationalisation (cost reduction). The results suggest that these cost-reducing process innovations are particularly focused on reducing employment requirements (see Peters, 2004, for more details).

Thirdly, we checked whether the growth in employment over the observed period might be measuring only a fraction of the total effect of innovation, with the remaining effect taking place after the end of the period. To test for this possibility, we included a variable from the Spanish data specifying what firms expect the change in their level of employment to be over the coming two years. The coefficient on expected employment growth was negative but insignificant, suggesting that we are not missing important dynamic effects in our preferred specification.

Finally, firms in the UK are asked separately about the proportion of their sales in 2000 that are accounted for by "significantly improved" and by "new products" stricto sensu, whereas firms in other countries are only asked about the proportion accounted for by "new or significantly improved" products. This allowed us to test whether our results would be significantly different if "new products" stricto sensu were distinguished from products that are merely significantly improved. In fact, our results remained practically unchanged. 


\section{Appendix B: Data}

\section{Country samples}

The Community Innovation Surveys (CIS) are carried out in European countries every four years, in general by the national statistical offices under the coordination of Eurostat. The questionnaire is harmonised, following the recommendations of the Oslo Manual; it includes some common "core" questions for all countries, as well as optional ones which can differ among countries. CIS3 is the survey performed in 2001, referring to the period 1998-2000. The institutions directly in charge were mainly INSEE and SESSI for France, ZEW for Germany, INE for Spain and the DTI for the United Kingdom. Firm participation in answering the questionnaire is compulsory in France and Spain, but only voluntary in Germany and the UK. Samples are representative, although the sampling frame differ across countries. A detailed analysis of the main characteristics of CIS3 for the four countries, as well as an assessment of its comparability, can be found in Abramovsky, Jaumandreu, Kremp and Peters (2004).

The samples used in the present study (corresponding to Tables $2 \mathrm{a}$ and $2 \mathrm{~b}$ in the text) have been defined and cleaned in order to improve their comparability in terms of industry composition and firm size coverage; they have also been slightly cleaned from a priori outliers, which could be particularly influential and strongly contaminate our econometric results. Firms which show significant reductions or increases in turnover as a result of mergers, closures or scissions have been excluded, as well as all firms which show incomplete data or changes in sales or employment higher than $300 \%$. The German sample has been restricted to firms with 10 or more employees to match the Spanish and UK samples. However, the French sample refers only to firms with 20 or more employees in manufacturing, and it does not include the transport industry in services. Table B1 gives the list of the eleven manufacturing industries and seven service industries covered in the study samples, as well as the number of firms and the average firm size by country and industry.

\section{Variable Definitions (in alphabetical order)}

Clients as source of information: Variable which takes the value 0 if the firm reports that clients as a source of information for innovation have not been used, 1 if they have been of 
low importance, 2 if they have been of medium importance and 3 if they have been of high importance.

Continuous REDD engagement: Dummy variable which takes the value 1 if the firms report continuous engagement in intramural $\mathrm{R} \& \mathrm{D}$ activities during the period.

Employment growth: Rate of change of the firm's employment for the whole period.

Expected employment growth: Rate of change in employment implied for expected employment in the coming two years (between 2000 and 2002).

Increased market share: Variable which takes the value 0 if the firm reports that the effect of innovation has been irrelevant for market share, 1 if it has had a low impact, 2 if it has had a medium impact, and 3 if it has had a high impact.

Increased range: Variable which takes the value 0 if the firm reports that the effect of innovation has been irrelevant for the broadening of the range of goods and services, 1 if it has had a low impact, 2 if it has had a medium impact, and 3 if it has had a high impact.

Industry dummies: System of industry dummies according to the list of industries given in Table B1.

Innovation effort: Ratio of $\mathrm{R} \& \mathrm{D}$ and other innovation expenditures to current turnover.

Improved quality: Variable which takes the value 0 if the firm reports that the effect of innovation has been irrelevant for the quality of goods and services, 1 if it has had a low impact, 2 if it has had a medium impact, and 3 if it has had a high impact.

Investment/sales98: Ratio of the value of investment during the period to the value of turnover in 1998.

Prices indices at detailed industry levels: For France, they are obtained for manufacturing and services at a 2.5-digit level of classification on the basis of the National Accounts valueadded deflators. For Germany, in manufacturing they are constructed at a 3-digit level (and in a few cases at a 2-digit level) on the basis of the producer price indices published by the German statistical office; in the service sector they have been obtained only at the level of the seven industries on the basis of the producer price indices or from different components on the consumer price indices (for details, see Peters, 2004). For Spain, for manufacturing they correspond to the 88-industry series of the "Indices de precios industriales" from INE, and for services to different components of the consumer price indices. For the UK, they are computed at a 4-digit level for manufacturing on the basis of the ONS output deflators, and at a 1.5-digit level for services on the basis of OECD output deflators. 
Process and product innovation: Dummy which takes the value 1 if the firm reports having introduced new or significantly improved products and production processes during the period.

Process innovation: Dummy which takes the value 1 if the firm reports having introduced new or significantly improved production processes during the period.

Process innovation of rationalisation: Dummy which takes the value 1 if the firm reports having introduced some process innovation with rationalisation (cost reduction) purposes during the period.

Process innovation only: Dummy which takes the value 1 if the firm reports having introduced new or significantly improved production processes during the period but no new or significantly improved products.

RESD effort: Ratio of total R\&D expenditure to current turnover.

Sales growth: Rate of change of the firm's turnover for the whole period (formally equal to $\left.g=\frac{P_{22} Y_{22}+P_{12} Y_{12}-P_{11} Y_{11}}{P_{11} Y_{11}}\right)$.

Sales growth due to new products: Computed as the product of the fraction of turnover due to new or significantly improved products and one plus the rate of change of the firm's turnover for the whole period (notice that, denoting $s$ as the proportion of sales in 2000 accounted for by new products, we have $\frac{P_{22} Y_{22}}{P_{22} Y_{22}+P_{12} Y_{12}}=s$ and hence $\left.g_{2}=\frac{P_{22} Y_{22}}{P_{11} Y_{11}}=s(1+g)\right)$.

Sales growth due to old products: Sales growth minus sales growth due to new products. 


\section{References}

Abramovsky, L., J. Jaumandreu, E. Kremp and B. Peters (2004), "National differences in innovation behaviour: Facts and explanations. Results using CIS3 data for France, Germany, Spain and the United Kingdom," mimeo, http://www.eco.uc3m.es/IEEF.

Benavente, J.M. and R. Lauterbach (2008), "The effect of innovation on employment, evidence from Chilean firms," forthcoming in The European Journal of Development Research.

Blanchflower, D. and S. Burguess (1998), "New technology and jobs: Comparative evidence from a two-country study," Economics of Innovation and New Technology, 5, 109-138.

Blechinger, D., A. Kleinknecht, G. Licht and F. Pfeiffer (1998), "The impact of innovation on employment in Europe. An analysis using CIS data," ZEW Discussion Paper 98-02, ZEW.

Brouwer, E., A. Kleinknecht and J. Reijnen (1993), "Employment growth and innovation at the firm level. An empirical study," Journal of Evolutionary Economics, 3, 153-159.

Chennells, L. and J. Van Reenen (2002), "Technical change and the structure of employment and wages: A survey on the microeconometric evidence," in Greenan, N., Y. L'Horty and J. Mairesse (eds.), Productivity, Inequality and the Digital Economy, MIT Press, $175-224$.

Doms, M., T. Dunne and M. Roberts (1995), "The role of technology use in the survival and growth of manufacturing plants," International Journal of Industrial Organization, 13, $523-542$.

Doraszelski, U. and J. Jaumandreu (2007), "R\&D and productivity: Estimating production functions when productivity is endogenous," mimeo, Harvard University and Universidad Carlos III.

Entorf, H. and W. Pohlmeier (1990), "Employment, innovation and export activity: Evidence from firm-level data," in Florens, J.P., M. Ivaldi, J.J. Laffont and F. Laisney (eds.), Microeconometrics: Surveys and applications, Oxford, 394-415. 
Evangelista, R. (2000), "Sectoral patterns of technological change in services," Economics of Innovation and New Technology, 9, 183-221.

Garcia, A., J. Jaumandreu and C. Rodriguez (2002), "Innovation and jobs: Evidence from manufacturing firms," UC3M, http://www.eco.uc3m.es/IEEF.

Greenan, N. and D. Guellec (2000), "Technological innovation and employment reallocation," Labour, 14, 547-590.

Griffith, R., E. Huergo, J. Mairesse and B. Peters (2006), "Innovation and productivity across four European countries," Oxford Review of Economic Policy, 22, 483-498.

Hall, B.H. and J. Mairesse (1995), "Exploring the relationship betwen R\&D and productivity in French manufacturing firms," Journal of Econometrics, 65, 263-293.

Hall, B.H., F. Lotti and J. Mairesse (2008), "Employment, innovation and productivity: Evidence from Italian microdata," forthcoming in Industrial and Corporate Change.

Huergo, E. and J. Jaumandreu (2004), "Firms' age, process innovation and productivity growth," International Journal of Industrial Organization, 22, 541-559.

Klette, T. and S.E. Forre (1998), "Innovation and job creation in a small open economy: Evidence from Norwegian manufacturing plants 1982-92," Economics of Innovation and New Technology, 5, 247-272.

König, H., G. Licht and H. Buscher (1995), "Employment, investment and innovation at the firm level," in OECD (ed.), The OECD jobs study. Investment, productivity and employment, Paris, 67-81.

Levinsohn, J. and A. Petrin (2003), "Estimating production functions using inputs to control for unobservables," Review of Economic Studies, 70, 317-341.

Mairesse J. and M. Sassenou (1991), "R\&D and productivity: a survey of econometric studies at the firm level," Science-Technology Industry Review, OECD, 8, 9-43.

Nickell, S. (1999), "Product markets and labour markets," Labour Economics, 6, 1-20.

Nickell, S. and P. Kong (1989), "Technical progress and jobs," Discussion Paper no. 366, Centre for Labour Economics, Oxford. 
OECD and Eurostat (1997), Oslo Manual, Proposed guidelines for collecting and interpreting technological innovation data, Paris.

Olley S. and A. Pakes (1996), "The dynamics of productivity in the telecommunications equipment industry," Econometrica, 64, 1263-1297.

Peters, B. (2004), "Employment effects of different innovation activities: Microeconometric evidence," ZEW Discussion Paper 04-73, ZEW.

Peters, B. (2008), "Innovation and firm performance: An empirical investigation for German firms," ZEW Economic Studies 38.

Regev, H. (1998), "Innovation, skilled labour, technology and performance in Israeli industrial firms," Economics of Innovation and New Technology, 5, 301-323.

Ross, D.R. and K. Zimmerman (1993), "Evaluating reported determinants of labour demand," Labour Economics, 1, 71-84.

Smolny, W. (1998), "Innovations, prices and employment. A theoretical model and an empirical application for West German manufacturing firms," Journal of Industrial Economics, 3, 359-381.

Smolny, W. (2002), "Employment adjustment at the firm level. A theoretical model and empirical investigation for West German manufacturing firms," Labour, 4, 65-88.

Spiezia, V. and M. Vivarelli (2002), "Innovation and employment: A critical survey," in Greenan, N., Y. L'Horty and J. Mairesse (eds), Productivity, Inequality and the Digital Economy, MIT Press, 101-131.

Triplett, J.E. and B.P. Bosworth (2004), Productivity in the US Services Sector. New Sources of Economic Growth, Brookings Institution Press.

Van Reenen, J. (1997), "Employment and technological innovation: evidence from UK manufacturing firms," Journal of Labour Economics, 2, 255-284. 
Table 1. Employment effects of innovation

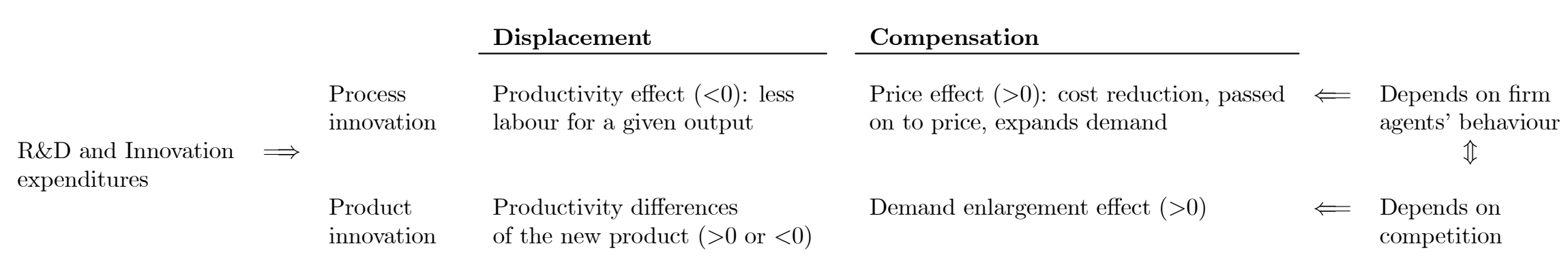


Table 2a. Manufacturing firms: Process and product innovators, growth of employment and sales, 1998-2000 ${ }^{1,2}$

\begin{tabular}{lcccc} 
& France & Germany & Spain & UK \\
\hline $\mathbf{N}^{\circ}$ of firms & 4631 & 1319 & 4548 & 2533 \\
Non-innovators (\%) & 47.7 & 41.5 & 55.4 & 60.5 \\
Process only (\%) & 7.1 & 10.2 & 12.2 & 11.0 \\
Product innovators (\%) & 45.2 & 48.4 & 32.4 & 28.5 \\
$\quad$ OOf which product \& process innovators] & {$[24.3]$} & {$[27.4]$} & {$[20.0]$} & {$[14.1]$}
\end{tabular}

\section{Employment growth (\%)}

All firms

$\begin{array}{llll}8.3 & 5.9 & 14.2 & 6.6 \\ 7.0 & 2.4 & 12.6 & 5.4 \\ 7.5 & 6.0 & 16.2 & 8.0 \\ 9.8 & 8.9 & 16.2 & 8.5\end{array}$

Sales growth ${ }^{3}(\%)$

$\begin{array}{lcccc}\text { All firms } & 13.0 & 15.2 & 23.2 & 12.3 \\ \text { Non-innovators } & 11.0 & 10.8 & 21.7 & 10.8 \\ \text { Process only } & 13.4 & 21.7 & 23.6 & 16.3 \\ \text { Product innovators } & 15.0 & 17.5 & 25.7 & 13.9 \\ \quad \text { of which: } & & & & \\ \quad \text { Old products } & -2.3 & -17.0 & -13.7 & -21.2 \\ \quad \text { New products } & 17.3 & 34.5 & 39.4 & 35.1\end{array}$

\section{Productivity growth (\%)}

All firms

Non-innovators

Process only

Product innovators

Prices growth $^{4}(\%)$

All firms

Non-innovators

Process only

Product innovators
4.7

4.0

5.9

7.5

2.5

2.5

3.1

2.4
9.3

8.4

15.7

8.7

1.3

1.1

2.4

1.3
9.0

$9.1 \quad 5.3$

$\begin{array}{ll}7.4 & 8.3\end{array}$

$9.5 \quad 5.4$

\footnotetext{
${ }^{1}$ Rates of growth for the whole period 1998-2000.

${ }^{2}$ Population is firms with 10 or more employees. Entrant firms and firms affected by mergers and scissions not considered.

${ }^{3}$ Sales growth for each type of firm is the average of variable $g$ and averages for old and new products are the averages of variables $\mathrm{g}_{1}$ and $\mathrm{g}_{2}$, respectively.

${ }^{4}$ Prices computed for a set of industries and assigned to firms according to their activity.
} 
Table 2b. Services firms: Process and product innovators, growth of employment and sales, 1998-2000 ${ }^{1,2}$

\begin{tabular}{|c|c|c|c|c|}
\hline & France & Germany & Spain & UK \\
\hline $\mathbf{N}^{o}$ of firms & 1653 & 849 & 1839 & 1794 \\
\hline Non-innovators (\%) & 60.2 & 51.4 & 69.1 & 70.2 \\
\hline Process only (\%) & 8.5 & 9.3 & 9.4 & 7.0 \\
\hline Product innovators (\%) & 31.3 & 39.3 & 21.5 & 19.8 \\
\hline [Of which product $\&$ process innovators] & {$[17.2]$} & {$[21.7]$} & {$[11.9]$} & {$[8.1]$} \\
\hline \multicolumn{5}{|l|}{ Employment growth (\%) } \\
\hline All firms & 15.5 & 10.2 & 25.9 & 16.1 \\
\hline Non-innovators & 14.2 & 5.9 & 24.8 & 13.8 \\
\hline Process only & 9.9 & 6.1 & 24.5 & 18.6 \\
\hline Product innovators & 19.4 & 16.9 & 30.1 & 23.7 \\
\hline \multicolumn{5}{|l|}{ Sales growth ${ }^{3}(\%)$} \\
\hline All firms & 18.4 & 18.5 & 32.3 & 22.7 \\
\hline Non-innovators & 16.3 & 14.4 & 30.9 & 21.2 \\
\hline Process only & 16.1 & 11.2 & 30.9 & 24.1 \\
\hline $\begin{array}{l}\text { Product innovators } \\
\text { of which: }\end{array}$ & 23.1 & 25.6 & 37.8 & 28.2 \\
\hline Old products & -3.2 & -15.9 & -8.9 & -14.1 \\
\hline New products & 26.3 & 41.5 & 46.7 & 42.2 \\
\hline \multicolumn{5}{|l|}{ Productivity growth (\%) } \\
\hline All firms & 2.9 & 8.3 & 6.4 & 6.7 \\
\hline Non-innovators & 2.1 & 8.5 & 6.1 & 7.4 \\
\hline Process only & 6.2 & 5.1 & 6.4 & 5.5 \\
\hline Product innovators & 3.7 & 8.7 & 7.7 & 4.5 \\
\hline \multicolumn{5}{|l|}{ Prices growth $^{4}(\%)$} \\
\hline All firms & 1.8 & 4.2 & 7.3 & 2.3 \\
\hline Non-innovators & 1.8 & 5.0 & 7.3 & 2.3 \\
\hline Process only & 1.8 & 4.7 & 7.3 & 1.0 \\
\hline Product innovators & 1.8 & 3.0 & 7.3 & 3.0 \\
\hline
\end{tabular}

\footnotetext{
${ }^{1}$ Rates of growth for the whole period 1998-2000.

${ }^{2}$ Population is firms with 10 or more employees. Entrant firms and firms affected by mergers and scissions not considered.

${ }^{3}$ Sales growth for each type of firm is the average of variable $g$ and averages for old and new products are the averages of variables $\mathrm{g}_{1}$ and $\mathrm{g}_{2}$, respectively.

${ }^{4}$ Prices computed for a set of industries and assigned to firms according to their activity.
} 
Table 3. The effects of innovation on employment

Dependent variable: $l-\left(g_{1}-\pi\right)$

Sector

Regression
MANUFACTURING

$\mathrm{A}(\mathrm{OLS})$

\begin{tabular}{ll}
\multicolumn{3}{c}{ SERVICES } \\
\hline $\mathrm{C}(\mathrm{OLS})$ & \\
$\mathrm{D}$ & $\mathrm{D}\left(\mathrm{IV}^{2}\right)$ \\
\hline
\end{tabular}

FR GE SP UK

$\begin{array}{lllllllllllll}\text { FR } & \text { GE } & \text { SP } & \text { UK } & \text { FR } & \text { GE } & \text { SP } & \text { UK } & \text { FR } & \text { GE } & \text { SP } & \text { UK } & \text { FR }\end{array}$

\begin{tabular}{|c|c|c|c|c|c|c|c|c|c|c|c|c|c|c|c|c|}
\hline Constant & $\begin{array}{l}-1.64 \\
(0.59)\end{array}$ & $\begin{array}{l}-4.55 \\
(1.17)\end{array}$ & $\begin{array}{l}-3.62 \\
(0.71)\end{array}$ & $\begin{array}{l}-4.21 \\
(0.81)\end{array}$ & $\begin{array}{l}-3.52 \\
(0.78)\end{array}$ & $\begin{array}{l}-6.95 \\
(1.36)\end{array}$ & $\begin{array}{l}-6.11 \\
(0.90)\end{array}$ & $\begin{array}{l}-6.30 \\
(0.85)\end{array}$ & $\begin{array}{l}-1.62 \\
(2.02)\end{array}$ & $\begin{array}{l}-1.96 \\
(2.64)\end{array}$ & $\begin{array}{l}-2.94 \\
(2.03)\end{array}$ & $\begin{array}{l}-3.72 \\
(1.54)\end{array}$ & $\begin{array}{l}-5.25 \\
(2.48)\end{array}$ & $\begin{array}{l}-3.36 \\
(3.05)\end{array}$ & $\begin{array}{l}-4.04 \\
(2.25)\end{array}$ & $\begin{array}{l}-5.51 \\
(1.61)\end{array}$ \\
\hline $\begin{array}{l}\text { Process innova- } \\
\text { tion only }(d)\end{array}$ & $\begin{array}{l}-2.88 \\
(1.53)\end{array}$ & $\begin{array}{l}-8.49 \\
(2.92)\end{array}$ & $\begin{array}{c}0.30 \\
(1.68)\end{array}$ & $\begin{array}{l}-5.49 \\
(1.84)\end{array}$ & $\begin{array}{l}-1.31 \\
(1.57)\end{array}$ & $\begin{array}{l}-6.19 \\
(2.92)\end{array}$ & $\begin{array}{c}2.46 \\
(1.78)\end{array}$ & $\begin{array}{l}-3.51 \\
(1.86)\end{array}$ & $\begin{array}{l}-4.49 \\
(3.30)\end{array}$ & $\begin{array}{l}-1.48 \\
(2.83)\end{array}$ & $\begin{array}{l}-1.05 \\
(3.26)\end{array}$ & $\begin{array}{c}1.80 \\
(3.56)\end{array}$ & $\begin{array}{l}-1.45 \\
(3.47)\end{array}$ & $\begin{array}{c}1.54 \\
(3.07)\end{array}$ & $\begin{array}{l}-0.38 \\
(3.37)\end{array}$ & $\begin{array}{c}3.21 \\
(3.54)\end{array}$ \\
\hline
\end{tabular}

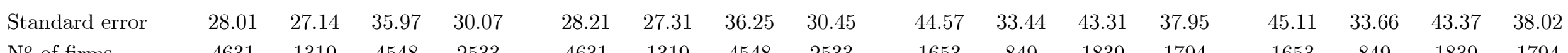

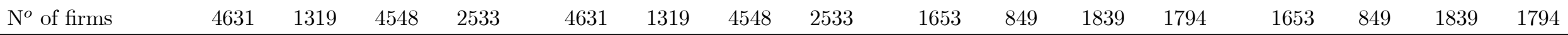

${ }^{1}$ Coefficients and standard errors robust to heteroskedasticity. All regressions include industry dummies.

${ }^{2}$ Unique instrument used is increased range. 
Table 4a. Testing the specification (Manufacturing)

Dependent variable: $l-\left(g_{1}-\pi\right)$

\begin{tabular}{|c|c|c|c|c|c|c|c|c|c|}
\hline \multirow[t]{2}{*}{ Regression } & \multicolumn{4}{|c|}{$\mathbf{A}^{2}$} & \multicolumn{4}{|c|}{$\mathbf{B}^{3}$} & \multirow{2}{*}{$\frac{\mathrm{C}^{4}}{\mathrm{GE}}$} \\
\hline & FR & GE & SP & UK & $\mathrm{FR}$ & GE & SP & UK & \\
\hline $\begin{array}{l}\text { Sales growth d.t. } \\
\text { new products }\left(g_{2}\right)\end{array}$ & $\begin{array}{c}0.97 \\
(0.06)\end{array}$ & $\begin{array}{c}0.97 \\
(0.06)\end{array}$ & $\begin{array}{c}1.01 \\
(0.04)\end{array}$ & $\begin{array}{c}0.99 \\
(0.05)\end{array}$ & $\begin{array}{c}0.98 \\
(0.06)\end{array}$ & $\begin{array}{c}1.04 \\
(0.06)\end{array}$ & $\begin{array}{c}0.97 \\
(0.04)\end{array}$ & $\begin{array}{c}1.00 \\
(0.05)\end{array}$ & $\begin{array}{c}1.02 \\
(0.07)\end{array}$ \\
\hline $\begin{array}{l}\text { Diff. Sargan }(\mathrm{m})^{5} \\
\text { Prob. value }\end{array}$ & $\begin{array}{c}1.80(1) \\
(0.18)\end{array}$ & $\begin{array}{c}1.20(1) \\
(0.27)\end{array}$ & $\begin{array}{c}0.27(1) \\
(0.60)\end{array}$ & $\begin{array}{c}0.48(1) \\
(0.49)\end{array}$ & - & - & - & - & - \\
\hline
\end{tabular}

${ }^{1}$ Coefficients and standard errors robust to heteroskedasticity. All regressions include industry dummies.

${ }^{2}$ Instruments used are increased range, clients as a source of information, and continuous REDD engagement.

${ }^{3}$ Instruments used are increased range, improved quality, increased market share and innovation effort.

${ }^{4}$ Instruments used are increased range and lagged R\&BD effort.

${ }^{5}$ Sargan denotes the test on overidentifying restrictions. Under the null hypothesis the test statistic is $\chi^{2}(m)$ distributed with the number $m$ of overidentifying restrictions. Diff. Sargan denotes the "difference-in-Sargan" statistic testing the exogeneity of process innovation. The statistic is distributed as a $\chi^{2}(1)$. 
Table 4b. Testing the specification (Services)

Dependent variable: $l-\left(g_{1}-\pi\right)$

\begin{tabular}{|c|c|c|c|c|c|c|c|c|}
\hline \multirow[t]{2}{*}{ Regression } & \multicolumn{4}{|c|}{$\mathbf{A}^{2}$} & \multicolumn{4}{|c|}{$\mathbf{B}^{3}$} \\
\hline & $\mathrm{FR}$ & $\mathrm{GE}$ & $\mathrm{SP}$ & UK & $\mathrm{FR}$ & $\mathrm{GE}$ & $\mathrm{SP}$ & UK \\
\hline Constant & $\begin{array}{l}-5.00 \\
(2.41)\end{array}$ & $\begin{array}{l}-3.68 \\
(3.01)\end{array}$ & $\begin{array}{l}-3.78 \\
(2.21)\end{array}$ & $\begin{array}{l}-5.41 \\
(1.60)\end{array}$ & $\begin{array}{l}-4.22 \\
(2.41)\end{array}$ & $\begin{array}{l}-3.96 \\
(2.75)\end{array}$ & $\begin{array}{l}-3.61 \\
(2.19)\end{array}$ & $\begin{array}{l}-5.42 \\
(1.61)\end{array}$ \\
\hline $\begin{array}{l}\text { Process innova- } \\
\text { tion only }(d)\end{array}$ & $\begin{array}{l}-1.66 \\
(3.46)\end{array}$ & $\begin{array}{c}1.84 \\
(3.00)\end{array}$ & $\begin{array}{l}-0.54 \\
(3.34)\end{array}$ & $\begin{array}{c}3.14 \\
(3.53)\end{array}$ & $\begin{array}{l}-2.31 \\
(3.46)\end{array}$ & $\begin{array}{c}2.41 \\
(2.93)\end{array}$ & $\begin{array}{l}-0.64 \\
(3.34)\end{array}$ & $\begin{array}{c}3.15 \\
(3.55)\end{array}$ \\
\hline $\begin{array}{l}\text { Sales growth d.t. } \\
\text { new products }\left(g_{2}\right)\end{array}$ & $\begin{array}{c}1.14 \\
(0.12)\end{array}$ & $\begin{array}{c}0.94 \\
(0.08)\end{array}$ & $\begin{array}{c}0.97 \\
(0.07)\end{array}$ & $\begin{array}{c}1.04 \\
(0.06)\end{array}$ & $\begin{array}{c}1.07 \\
(0.11)\end{array}$ & $\begin{array}{c}0.97 \\
(0.07)\end{array}$ & $\begin{array}{c}0.96 \\
(0.07)\end{array}$ & $\begin{array}{l}1.04 \\
(0.06)\end{array}$ \\
\hline $\begin{array}{l}\text { Standard error } \\
\mathrm{N}^{o} \text { of firms }\end{array}$ & $\begin{array}{l}45.04 \\
1653\end{array}$ & $\begin{array}{c}33.77 \\
849\end{array}$ & $\begin{array}{c}43.35 \\
1839\end{array}$ & $\begin{array}{c}38.00 \\
1794\end{array}$ & $\begin{array}{l}44.85 \\
1653\end{array}$ & $\begin{array}{c}34.00 \\
849\end{array}$ & $\begin{array}{l}43.34 \\
1839\end{array}$ & $\begin{array}{c}38.16 \\
1794\end{array}$ \\
\hline $\begin{array}{l}\text { Sargan }(\mathrm{m})^{4} \\
\text { Prob. value }\end{array}$ & $\begin{array}{c}0.41(2) \\
(0.81)\end{array}$ & $\begin{array}{c}1.09(2) \\
(0.58)\end{array}$ & $\begin{array}{c}0.28(2) \\
(0.87)\end{array}$ & $\begin{array}{c}3.75(2) \\
(0.15)\end{array}$ & $\begin{array}{c}13.97(3) \\
(0.00)\end{array}$ & $\begin{array}{c}7.71(3) \\
(0.05)\end{array}$ & $\begin{array}{c}5.48(3) \\
(0.14)\end{array}$ & $\begin{array}{c}12.48(3) \\
\quad(0.01)\end{array}$ \\
\hline $\begin{array}{l}\text { Diff. Sargan }(\mathrm{m})^{4} \\
\text { Prob. value }\end{array}$ & $\begin{array}{c}0.01(1) \\
(0.92)\end{array}$ & $\begin{array}{c}0.01(1) \\
(0.92)\end{array}$ & $\begin{array}{c}0.03(1) \\
(0.86)\end{array}$ & $\begin{array}{c}0.59(1) \\
(0.44)\end{array}$ & - & - & - & - \\
\hline
\end{tabular}

${ }^{1}$ Coefficients and standard errors robust to heteroskedasticity. All regressions include industry dummies.

${ }^{2}$ Instruments used are increased range, clients as a source of information, and continuous RED engagement.

3 Instruments used are increased range, improved quality, increased market share and innovation effort.

${ }^{4}$ Sargan denotes the test on overidentifying restrictions. Under the null hypothesis the test statistic is $\chi^{2}(m)$ distributed with the number $m$ of overidentifying restrictions. Diff. Sargan denotes the "difference-in-Sargan" statistic testing the exogeneity of process innovation. The statistic is distributed as a $\chi^{2}(1)$. 
Table 5.

Contributions of innovation to employment growth ${ }^{1}$

Manufacturing and Services, 1998-2000 ${ }^{2}$

France Germany Spain UK

Manufacturing (Average values) ${ }^{3}$

Firms' employment growth

Productivity trend in production of old products ${ }^{4}$

$\begin{array}{cccc}8.3 & 5.9 & 14.2 & 6.7 \\ -1.9 & -7.5 & -5.7 & -6.8 \\ -0.1 & -0.6 & 0.3 & -0.4 \\ 4.8 & 6.0 & 12.2 & 9.0 \\ 5.5 & 8.0 & 7.4 & 4.8\end{array}$

Gross effect of process innovation in production of old products

Output growth of old products contribution

Net contribution of product innovation

Germany

Spain UK

Services (Average values) ${ }^{3}$

Firms' employment growth

Productivity trend in production of old products ${ }^{4}$

$\begin{array}{cccc}15.5 & 10.2 & 25.9 & 16.1 \\ -2.3 & -3.0 & 1.0 & -5.0 \\ -0.1 & 0.1 & -0.0 & 0.2 \\ 9.9 & 5.4 & 18.5 & 15.5 \\ 8.0 & 7.6 & 6.5 & 5.4\end{array}$

Gross effect of process innovation in production of old products

Output growth of old products contribution

${ }^{1}$ Decomposition based on regressions B and D of Table 3.

2 Rates of growth for the whole period.

3 The sum of decomposition values may differ slightly from employment growth because of rounding.

${ }^{4}$ Productivity trend is the weighted sum of industry dummy values and hence differs from the constant of the regression. 
Table A1. Manufacturing and Services

Exploratory OLS regressions: employment growth on sales growth and innovation dummies ${ }^{1}$

Dependent variable: $l$

Sector

\begin{tabular}{lll}
\multicolumn{4}{c}{ A (Manufacturing) } \\
\hline FR $\quad$ GE SP UK
\end{tabular}

\begin{tabular}{lll}
\multicolumn{4}{c}{ B (Services) } \\
\hline FR & GE $\quad$ SP & UK
\end{tabular}

Explanatory variables

\begin{tabular}{|c|c|c|c|c|c|c|c|c|}
\hline Constant & $\begin{array}{c}2.52 \\
(0.53)\end{array}$ & $\begin{array}{l}-2.21 \\
(0.74)\end{array}$ & $\begin{array}{c}6.59 \\
(0.59)\end{array}$ & $\begin{array}{l}-0.62 \\
(0.62)\end{array}$ & $\begin{array}{c}5.15 \\
(2.23)\end{array}$ & $\begin{array}{c}2.71 \\
(1.87)\end{array}$ & $\begin{array}{c}8.44 \\
(1.67)\end{array}$ & $\begin{array}{c}6.10 \\
(1.31)\end{array}$ \\
\hline Real sales growth: $\left(g_{1}-\pi\right)$ & $\begin{array}{c}0.43 \\
(0.02)\end{array}$ & $\begin{array}{c}0.43 \\
(0.04)\end{array}$ & $\begin{array}{c}0.35 \\
(0.02)\end{array}$ & $\begin{array}{c}0.48 \\
(0.03)\end{array}$ & $\begin{array}{c}0.45 \\
(0.04)\end{array}$ & $\begin{array}{c}0.49 \\
(0.04)\end{array}$ & $\begin{array}{c}0.48 \\
(0.03)\end{array}$ & $\begin{array}{c}0.46 \\
(0.03)\end{array}$ \\
\hline Process innovation only $(d)$ & $\begin{array}{l}-0.54 \\
(1.17)\end{array}$ & $\begin{array}{l}-0.49 \\
(1.20)\end{array}$ & $\begin{array}{c}2.98 \\
(1.25)\end{array}$ & $\begin{array}{l}-0.29 \\
(1.56)\end{array}$ & $\begin{array}{l}-3.78 \\
(2.73)\end{array}$ & $\begin{array}{l}-0.12 \\
(1.97)\end{array}$ & $\begin{array}{c}0.57 \\
(2.60)\end{array}$ & $\begin{array}{c}3.68 \\
(3.29)\end{array}$ \\
\hline Product innovation ${ }^{2}$ & $\begin{array}{c}1.11 \\
(0.72)\end{array}$ & $\begin{array}{c}3.99 \\
(1.21)\end{array}$ & $\begin{array}{c}2.0 \\
(0.88)\end{array}$ & $\begin{array}{c}2.29 \\
(1.28)\end{array}$ & $\begin{array}{c}3.30 \\
(2.74)\end{array}$ & $\begin{array}{c}3.94 \\
(1.85)\end{array}$ & $\begin{array}{c}2.82 \\
(2.31)\end{array}$ & $\begin{array}{c}5.57 \\
(2.05)\end{array}$ \\
\hline $\begin{array}{l}\mathrm{N}^{o} \text { of firms } \\
\text { Standard error }\end{array}$ & $\begin{array}{l}4631 \\
21.64\end{array}$ & $\begin{array}{l}1319 \\
19.31\end{array}$ & $\begin{array}{c}4548 \\
26.10\end{array}$ & $\begin{array}{l}2533 \\
24.27\end{array}$ & $\begin{array}{c}1653 \\
39.33\end{array}$ & $\begin{array}{c}849 \\
23.50\end{array}$ & $\begin{array}{l}1839 \\
36.09\end{array}$ & $\begin{array}{c}1794 \\
30.13\end{array}$ \\
\hline
\end{tabular}

${ }^{1}$ Coefficients and standard errors robust to heteroskedasticity. All regressions include industry dummies.

2 Product innovators only and product and process innovators. 
Table A2. Alternative assumptions about process innovations

Dependent variable: $l-\left(g_{1}-\pi\right)$

Sector

Regression

Regension

MANUFACTURING

$\overline{\mathbf{A}\left(\mathbf{I V}^{2}\right)} \longrightarrow \mathbf{B ( \mathbf { I V } ^ { 3 } )}$

$\begin{array}{r}\text { SERVICE } \\ \hline \mathbf{C}\left(\mathbf{I V}^{2}\right) \\ \hline\end{array}$

FR GE SP UK

FR $\quad$ GE $\quad$ SP $\quad$ UK

Constant

Constant

Process innova-

$\begin{array}{llll}-3.51 & -6.96 & -6.14 & -6.33 \\ (0.78) & (1.37) & (0.91) & (0.88)\end{array}$

$\begin{array}{llll}(0.78) \quad(1.37) \quad(0.91) \quad(0.88) & 0\end{array}$

$\begin{array}{llll}-3.50 & -6.97 & -6.12 & -6.24 \\ (0.78) & (1.37) & (0.90) & (0.84)\end{array}$

$\begin{array}{llll}(0.78) & (1.37) \quad(0.90) \quad(0.84)\end{array}$

$\begin{array}{llll}-1.32 & -6.18 & 2.47 & -3.54\end{array}$

$\begin{array}{llll}(1.57) & (2.92) \quad(1.78) \quad(1.85)\end{array}$

$(1.56) \quad(2.92) \quad(1.79) \quad(1.85)$

$\begin{array}{lcccc}\text { Process \& product } & 2.59 & -1.98 & -1.49 & 4.94\end{array}$

innovation

$(1.43) \quad(2.80) \quad(2.64) \quad(2.56)$

$\begin{array}{lllll}\text { Sales growth d.t. } & 0.90 & 1.04 & 1.05 & 0.92\end{array}$

new products $\left(\begin{array}{lllll}\left.g_{2}\right) & (0.09) & (0.07) & (0.07) & (0.07)\end{array}\right.$

Sales growth d.t.

new products

$\times$ process inno.$$
\text { SP }
$$

UK

$\begin{array}{llll}-4.96 & -3.39 & -3.82 & -5.45 \\ (2.44) & (3.04) & (2.20) & (1.62)\end{array}$

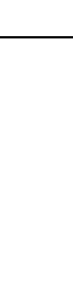

$\begin{array}{cccc}-1.63 & 1.56 & -0.46 & 3.10 \\ (3.47) & (3.06) & (3.36) & (3.53)\end{array}$

$\begin{array}{cccc}-3.81 & 1.80 & -6.52 & -6.26 \\ (5.55) & (4.26) & (6.72) & (4.96)\end{array}$

$\begin{array}{llll}1.23 & 0.90 \quad 1.07 & 1.10\end{array}$

$\begin{array}{llll}(0.18) & (0.11) \quad(0.14) \quad(0.09)\end{array}$

$\begin{array}{cccc}0.14 & -0.04 & -0.02 & 0.14 \\ (0.08) & (0.07) & (0.06) & (0.08)\end{array}$

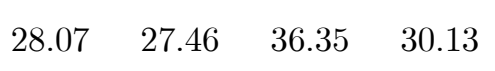

$\begin{array}{cccc}1.18 & 0.86 & 1.13 & 1.10 \\ (0.17) & (0.11) & (0.12) & (0.10) \\ & & & \\ -0.04 & 0.09 & -0.23 & -0.10 \\ (0.20) & (0.10) & (0.12) & (0.11)\end{array}$

$\begin{array}{llll}(0.20) \quad(0.10) & (0.12) \quad(0.11)\end{array}$

\begin{tabular}{|c|c|c|c|c|c|c|c|c|c|c|c|c|c|c|c|c|}
\hline Standard error & 28.07 & 27.46 & 36.35 & 30.13 & 28.20 & 27.27 & 36.26 & 30.19 & 45.36 & 33.53 & 43.51 & 38.19 & 45.11 & 33.76 & 43.25 & 38.07 \\
\hline $\mathrm{N}^{o}$ of firms & 4631 & 1319 & 4548 & 2533 & 4631 & 1319 & 4548 & 2533 & 1653 & 849 & 1839 & 1794 & 1653 & 849 & 1839 & 1794 \\
\hline
\end{tabular}

\footnotetext{
${ }^{1}$ Coefficients and standard errors robust to
${ }^{2}$ Unique instrument used is increased range.

${ }^{3}$ Instruments are increased range and increased range interacted with process innovation.
} 
Table B1. Number of firms and average firm size, by country and sector.

\begin{tabular}{|c|c|c|c|c|c|c|c|c|}
\hline & \multicolumn{4}{|c|}{ Number of firms (\%) } & \multicolumn{4}{|c|}{ Average firm size ${ }^{1}$} \\
\hline & $\mathrm{FR}$ & GE & $\mathrm{SP}$ & UK & $\mathrm{FR}$ & $\mathrm{GE}$ & $\mathrm{SP}$ & UK \\
\hline \multicolumn{9}{|l|}{ Manufacturing } \\
\hline Vehicles & 4.3 & 4.0 & 5.6 & 10.5 & 1164 & 340 & 367 & 222 \\
\hline Chemicals & 8.2 & 7.0 & 6.5 & 3.7 & 483 & 330 & 213 & 337 \\
\hline Machinery & 9.2 & 14.0 & 6.3 & 8.0 & 302 & 291 & 150 & 179 \\
\hline Electrical & 9.9 & 16.2 & 8.1 & 15.7 & 540 & 482 & 157 & 197 \\
\hline Food & 19.3 & 8.6 & 11.0 & 7.2 & 282 & 149 & 150 & 303 \\
\hline Textile & 12.3 & 5.8 & 14.7 & 5.7 & 124 & 219 & 78 & 148 \\
\hline Wood & 9.1 & 8.5 & 13.8 & 14.6 & 234 & 358 & 87 & 144 \\
\hline Plastic/rubber & 6.0 & 8.8 & 4.4 & 5.1 & 396 & 148 & 105 & 132 \\
\hline Non-metallic & 3.5 & 5.9 & 7.3 & 2.3 & 415 & 247 & 141 & 242 \\
\hline Basic metal & 13.3 & 17.2 & 13.4 & 14.1 & 258 & 153 & 110 & 68 \\
\hline NEC & 4.9 & 4.0 & 8.9 & 13.2 & 217 & 253 & 66 & 132 \\
\hline All firms & 100 & 100 & 100 & 100 & 345 & 276 & 132 & 171 \\
\hline \multicolumn{9}{|l|}{ Services } \\
\hline Wholesale & 44.9 & 24.0 & 22.1 & 41.4 & 62 & 410 & 146 & 124 \\
\hline Transport & 0.0 & 24.0 & 18.5 & 25.9 & - & 1272 & 373 & 291 \\
\hline Post/telecomm. & 1.9 & 3.1 & 4.1 & 3.6 & 102 & 220 & 191 & 587 \\
\hline Financial int. & 15.2 & 11.4 & 7.0 & 13.3 & 1044 & 808 & 527 & 282 \\
\hline Computers & 12.8 & 9.4 & 9.8 & 4.4 & 81 & 95 & 151 & 238 \\
\hline $\mathrm{R} \& \mathrm{D}$ & 3.9 & 8.8 & 3.9 & 1.9 & 168 & 91 & 68 & 338 \\
\hline Technical serv. & 21.4 & 19.2 & 34.6 & 9.6 & 129 & 56 & 301 & 136 \\
\hline All firms & 100 & 100 & 100 & 100 & 233 & 531 & 268 & 215 \\
\hline
\end{tabular}

${ }^{1}$ Average firm size is measured by the average number of employees in the year 2000 . 